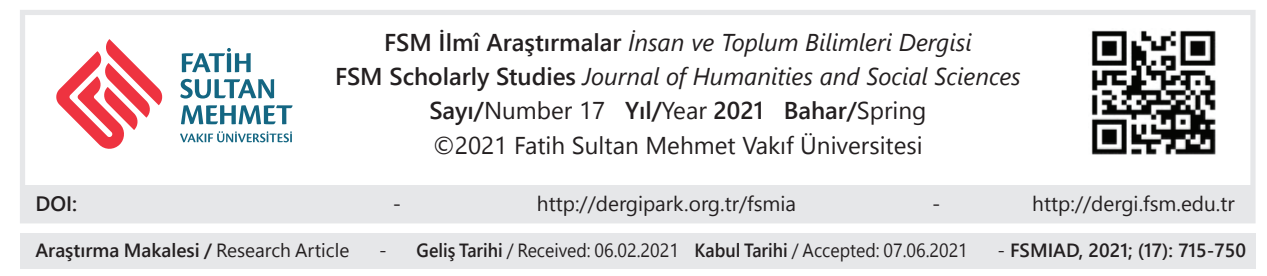

\title{
TV Dizi Adlarında Türkçenin Diğer Dillerle Etkileşimine Yönelik Betimsel Bir Çalışma
}

Gülşah Parlak Kalkan*

\section{$\ddot{O} z$}

Bu araştırmada Türkiye'de reyting sıralamasında önde olan Atv, Fox, Kanal D, Kanal 7, Show, Star ve TRT 1'de 1990'lı yıllardan 2020 yılına kadar yayınlanan dizi adlarından seçkisiz örneklem şeklinde oluşturulan verideki kelimeleri köken bakımından sınıflandırmak suretiyle Türkçenin hangi dil ile ne ölçüde etkileşim hâlinde olduğunun tespiti amaçlanmış ve ulaşılan sonuçlar, Türk dil/kültür tarihi ile uygunluğu bakımından değerlendirilmiş̧ir. Araştırma verileri için ilgili kanalların internet sitelerinden derlenen 576 dizi adındaki kelimeler, örnek durum çalışması tekniği ile incelenmiş ve içerik analizi yapılarak deşifre edilen veriler çeşitli tasniflerle değerlendirilmiştir. Sonuçta TV dizi adlarındaki kelimelerin \%55'inin Türkçe, \%31'inin Arapça, \%8'inin Farsça, \%4.5'inin batı kökenli ve \%2'sinin de kökeninin belirsiz olduğu tespit edilmiştir. Dolayısıyla dizi adlarında Türkçe açısından betimlenen durumun Türk dil/kültür tarihi ile bağının günümüzde de kuvvetli olduğunu söylemek mümkündür.

Anahtar Kelimeler: Dizi adı, Türkçe dizi adları, alıntı kelime.

* Dr. Öğr. Üyesi, Kilis 7 Aralık Üniversitesi Türkçe ve Sosyal Bilimler Eğitimi Bölümü, Kilis/ Türkiye,gulsah.parlak@hotmail.com,orcid.org/0000-0003-0986-9768 


\title{
A Descriptive Study on the Interaction of Turkish with Other Languages in TV Series Titles
}

\begin{abstract}
In this study, in order to classify the words in the data formed as a random sample of the series names from the 1990s to 2020 in Atv, Fox, Kanal D, Kanal 7, Show, Star and TRT 1, which are at the top of the rating order in Turkey, to classify the words in terms of origin and It was aimed to determine the extent of interaction with the language and the results obtained were examined in terms of their compatibility with the Turkish language / cultural history. The words in 576 series, which were compiled from the websites of the relevant channels for the research data, were analyzed with the case study technique and the data deciphered by content analysis was evaluated with various classifications. As a result, it has been determined that $55 \%$ of the words in TV series names are Turkish, $31 \%$ Arabic, $8 \%$ Persian, $4.5 \%$ Western and 2\% uncertain origin. Therefore, it is possible to say that the situation described in terms of Turkish in the series titles and the Turkish language / cultural history is still strong today.
\end{abstract}

Keywords: Series name, Turkish series names, citation word. 


\section{Giriş}

İnsan topluluklarının bir araya gelerek millet kimliği kazanmasının ve bu kimliğin devamını sağlamasının ilk şartı hiç şüphesiz ortak anlaşma aracı olan bir dildir. Nitekim millet kelimesi tanımlanırken "aynı dili konuşan..." şeklindeki ifade ile söze başlanır ve "dil birliği" ilk temel unsur olarak vurgulanır. $\mathrm{Bu}$ bakımdan canlının insan evresine geçebilmesini sağlayan dilin aynı zamanda ilim ve kültürün de temelini oluşturduğunu söylemek mümkündür. İslam medeniyeti, Osmanlı medeniyeti, Roma medeniyeti, Avrupa medeniyeti gibi örneklerde görüleceği üzere kültür ve medeniyet tarihinde yüksek mertebelere erişmiş kuvvetli kültürlerin zengin ve güçlü dillerin eseri olduğu görülmektedir. Dolayısıyla milleti bir bütün olarak ayakta tutan ve nesilleri birbirine bağlayıp devamlılığ 1 sağlayan zincir dil olduğu için dilin gücünü yitirip çökmesi, milleti oluşturan bireylerin arasındaki bağın zayıflaması ve zamanla milletin dağılması, kaybolması demektir.

Bugün konuşan insan sayısının fazlalığı ve konuşulan coğrafyanın geniş̧liği ile birlikte Uzak Doğu kültür ve medeniyetinin gelişmiş bir yazı dili olan Türkçe, daha VIII. yüzyılda devrinin dinî, edebî, felsefi duygu ve düşünce dünyasından insan zekâsının tüm mahsullerine kadar her şeyi eksiksiz bir biçimde ifade edebilen güçte bir dildi. Henüz yeryüzünde Latince, Grekçe, Arapça, Farsça ve Çinceden başka hiçbir kültür dili bulunmazken Göktürk ve Uygur dönemlerinde edebiyat tarihinin edebî ve felsefi açıdan çok kıymetli eserlerini vücuda getiren Türkçe, en eski dönemlerden bu yana çeşitli sosyal ve siyasal sebeplerle birbirinden bağımsız pek çok sahaya yayılmış; yayıldığı her sahada tanıştığı kültürlerle ve dolayısıyla dillerle etkileşim yaşamış ve kullanıldığ 1 her dönemde oldukça zengin ve güçlü bir kültür dili olarak ayakta kalmayı başarmıştır. ${ }^{1}$

Tarih boyunca hemen her dönemde yabancı dil ve kültürlere hoşgörü ile yaklaşan Türkler ve dolayısıyla Türkçe, karşılaştığı her kültür ve dil ile etkileşim yaşamış; gelişmiş, zenginleşmiş ve günümüze kadar gelmiştir.

Toplumlar arasındaki bu etkileşim, öncelikle dil ilişkileri şeklinde gelişmekte ve dil ilişkileri ise kültürel öğelerin birbirinden öğrenilmesine bağlı olarak gerçekleşen kelime alışverişi ile sürdürülmektedir. Bu bakımdan dünyada konuşulan bütün diller, konuşurlarının ekonomik ya da kültürel faaliyetlerine bağlı olarak birbirleriyle daima etkileşim halinde oldukları için yeryüzünde saf halini koruyan bir dilin varlığından söz etmek pek mümkün değildir. ${ }^{2}$ Bu noktada önemli olan

1 Necmettin Hacıeminoğlu, Türkçenin Karanlık Günleri, İstanbul, İrfan Yayınevi, 1976, s. 51.

2 Ümit Yıldız - Gülsüm Sertoğlu, "Esnaf Tabelalarında Yabanc1 Kelime Dağılımı Üzerine Bir Çalışma”, Route Educational and Social Science Journal, 6(7), 2019, s. 1095. 
etkileşim ve alışveriş esnasında ölçüyü kaçırmamak ve dillerin iç/dış yapısına zarar verecek alıntılamalardan uzak durmaktır. ${ }^{3}$

Diller arası etkileşimde ve alışverişte en geniş yer tutan kelime alıntılamalarıdır. Her dil, kültürel alışveriş içerisinde olduğu toplumların dillerinden ya da onlar aracılığıyla başka dillerden kelimeler alır. Bu kelimelerin bir kısmı hiçbir değişime uğramadan kullanılırken büyük bir kısmı da alıcı dilin ses ve şekil yapısına uygun hale getirilir. ${ }^{4}$ Bazen de kaynak dilden farklı olarak kelimelere yeni anlamlar yüklenir. ${ }^{5} \mathrm{O}$ halde kelime alıntılamasının iki farklı boyutundan söz etmek mümkündür:

1. Dilin ses yahut işletim kurallarına uymuş, yabancıllı̆̆ neredeyse belli olmayan kelimeler: duvar ( $<$ Farsça divâr), surat ( $<$ Arapça sûret) vb.

2. Dilin, ses eğilim ve kurallarına uymayan, yabancılığ dir: oksijen, lokomotif, devalüasyon vb. ${ }^{6}$

2005 yılı itibarıyla 104.481 kelimenin bulunduğu Güncel Türkçe Sözlük’te 6.463 Arapça alıntı kelime ve 1.374 Farsça alıntı kelime yer almaktadır. Bu kelimelerin bazıları Türkiye Türkçesinde kendi ses değerlerini korurken, bazıları da küçük ya da büyük değişmelere uğramıştır. Hatta günümüze gelinceye kadar Türkçe, bu kelimelerden bazılarını kendi bünyesinde öyle bir forma ulaştırmıştır ki bu kelimeler, bir Arap'ın anlayamayacağı kadar Türk'ün ve Türkçenin (hokkabaz < hukka+bâz, kalpazan < kalb-zen, kumarbaz < kimâr+bâz) malı olmuştur. ${ }^{7}$

Türkçenin geçmişten günümüze etkileşim yaşadığı dillere bakıldığında, Uygur Dönemindeki birtakım çeviri eserler göz ardı edilirse en çok çeviri eserin ve kelime alıntılamanın Arapça ve Farsçadan yapıldığı görülür. ${ }^{8}$

Türkçenin yüzyıllardır etkileşim yaşadığı Arapça ve Farsça ile ilişkisi X. yüzyılda Türklerin Müslümanlığı kabul etmeleri ile başlamış; günümüze kadar da devam etmiştir. Daha o yüzyıllardan başlayarak Arapça din dili konumunda, tüm Müslüman devletleri ve halkları arasında çok etkili olmuştur. Elbette yeni

3 Rabia Şenay Şişman, “İ̧̧ Yeri Adlandırma Eğilimleri: Muş Merkez Modeli”, Turkish Studies, 5(1), 2018, s. 892.

4 Okan Celal Güngör, "Karaçay-Malkar Türkçesindeki Arapça ve Farsça Alıntı Sözlerde Ses ve Anlam Değişmeleri”, Dil Araştırmaları, 25, 2019, s. 140.

5 Emrullah İşler, "Türkçede Anlam Kaymasına Uğrayan Arapça Kelime ve Kelime Grupları”, İstanbul, Türk Dünyası Araştırmaları Vakfi, 1996.

6 Doğan Aksan, Türkçenin Sözvarlı̆̆l, Ankara, Engin Yayınevi, 2006, s. 29.

7 Halit Dursunoğlu, “Türkiye Türkçesindeki Arapça Sözcükler ve Bu Sözcüklerdeki Ses Olaylar1”, Turkish Studies, 9(9), 2014, s. 518-521.

$8 \quad$ Aksan, a.g.e., s. 39. 
Müslüman olan toplumlar, kabul ettikleri dinin kutsal kitabı Kur'an’1 okumak ve anlamak için Arap alfabesini ve Arapçayı öğrenmek istemişlerdir. Başlangıçta "Kur'an'ı ögrrenmek ve anlamak" için başlayan Arapça bilgisi, medreselerde okutulan Kur'an, Hadis, Tefsir, Kelam, Fıkıh gibi derslerle kurumsal bir kimlik kazanmıştır. Dolayısıyla Türkçe-Arapça ilişkisinin temelinde Müslümanlığın olduğunu söylemek mümkündür. Benzer durumun Batı dünyasında da örneği mevcuttur. Roma İmparatorluğu'nun resmi dili olan Latince, dinî meselelerde olduğu gibi bürokrasi alanında da devletin dili olmuştur. ${ }^{9}$

Türkçedeki Arapça alıntılar, dinî alıntılar ve kültürel alıntılar olmak üzere iki farklı mecrada gerçekleşmiştir. Arapçadan Müslümanlıkla ilgili alınan pek çok terim zamanla salt dinî terim olarak kalmamış, ticaret, hukuk alanlarında da kullanılmıştır: ayet, azap, dua, enbiya, küfür, mahluk, mücadele, nikâh, sulh, şeriat vb. Tabii, bu iki dil arasında din temelli başlayan ilişkiler, başlangıçta Arapçayı kaynak dil konumuna oturtmuş olsa da bir süre sonra Türkçenin de çeşitli alanlarda Arapça lehçe ve ağızlarına pek çok kelime vermesiyle her iki dil için de kaynak dil şeklinde gelişmiş ve devam etmiştir. Türkçenin Arapçaya verdiği kelimelerin başında kullanım sıklığı ve yaygınlık açısından ilk sırada yer alan ağa, alay, binbaş1, bombac1, bölük, kışla, koğuş, ordu, paşa gibi kelimelerdir. Türkçeden Arapçaya yayılan diğer bir alıntı türü ise Türkçe meslek isimleri yapan $+\mathrm{CI}$ eki ile oluşturulan çeşitli meslek isimleridir: tulumbacı, kapıcı, kumaşçı, arzuhâlci, mumcu, nalcı, sabuncu gibi. Nitekim bu örnekler Türkçe-Arapça arasındaki ilişkilerin dine bağlı Arapça dinî terminoloji ya da askerî bakımdan üstün konumda olan Türklerin Arapçaya vermiş oldukları askerî terimler ile sınırlı kalmadığını, Osmanlı İmparatorluğu'nun hâkim olduğu tüm coğrafyaya bürokrasi ve zanaatkâr diline ait terminolojiyi de ulaştırarak ortak bir mesleki terminoloji kurduğunu da göstermektedir. ${ }^{10}$

Türkçe-Farsça ilişkisi ise Türkçe-Arapça ilişkisinden daha eski tarihlere dayanmaktadır. Farsça daha III. yüzyılda Sâsânîlerden itibaren, Türkçe ise IX. yüzyıldan itibaren Orta Asya'da yerleşik bir kültür ve uygarlık dili olarak varlığını sürdürmüş; Türkçe-Farsça ilişkisi de iki halkın erken dönemlerde aynı coğrafyayı paylaşması ile başlamıştır. 642 yılında Nihavend Savaşı'nda Sâsânîlerin yenilmesi ile Orta Asya Türklere açılmış; Köktürkler ile Sâsânîler, siyasi, askerî ihtilaflar dışında kültür ve dil alanlarında da etkileşmişlerdir. Gazneliler zamanında Farsça gerek devlet katında gerekse şairler ve yazarlar arasında en itibarlı

9 Ali Akar, “Türkçe-Arapça Arasındaki Sözcük İlişkileri”, Karadeniz Uluslararası Bilimsel Dergi, 8, 2010.

10 Akar, a.g.m., s. 9-15. 
dil olmuş, Selçuklular döneminde ise Farsça yüzyıllar boyunca devletin yazışma dili olmuştur. Türklerin Araplarla karşılaştıkları X. yüzyılda, Farsçanın Türkçe üzerinde önemli derecede etkisi bulunmakta idi. Hatta Türkler, Müslümanlığın yazılı kaynaklarına aracı dil Farsça üzerinden ulaşmışlardır. ${ }^{11}$

XV. ve XVI. yüzyıllara gelindiğinde ise Rönesans ve Reform hareketleriyle “Aydınlanma Çağı”na giren Batı, tüm dünyayı etkilemiş ve Osmanlı Devleti’nde Tanzimat Fermanı ile adeta resmi bir anlam kazanan Batılılaşma, sosyal ve fikrî hayatı olduğu kadar dili de etkilemiştir. Neticede Tanzimat'tan itibaren Türkçeye, Batı dillerinden kelimeler girmeye başlamış; önce Fransızcadan, I. Dünya Savaşı'ndan 1940'lara kadar Almancadan, II. Dünya Savaşı'ndan sonra da İngilizceden kelimeler alınmıştır. ${ }^{12}$

Günümüzde ise bu durum değişmemiş olmakla birlikte önceki dönemlerde Fransızca aracılığıyla dilimize girmiş ve ses, şekil bakımından Türkçenin malı olmuş kimi kelimeler dahi İngiliz veya Amerikan telaffuzuna göre söylenir olmuştur. Özellikle son yıllarda teknolojik gelişmelere bağlı iletişim araçlarının çeşitlenmesi, bilgisayar ve internet kullanımının artması dünyayı adeta küçük bir kasaba hâline dönüştürmüştür. Bugün eğitimden sağlığa pek çok alanda olduğu gibi sanal ortamda da baskın dil olan İngilizcenin hem söz varlığı hem de ses/şekil, gramer hususiyetleri açısından Türkçeye etkisi, en üst düzeyde hissedilmektedir. Dolayısıyla kitle iletişim araçlarında kullanılan Türkçenin durumu, değişik mecralarda sık sik tartışılan önemli mevzulardandır.

\section{Kitle İletişimi ve Türkçe}

İletişim; duygu, düşünce ve bilgi paylaşımı gerçekleştirmek üzere alıcı ve vericinin ortak bir zaman ve mekânda yaşadığ 1 etkileşim durumudur. Dolayısıyla dilsel iletişimin altı temel öge üzerinde kurulduğunu söylemek mümkündür: ${ }^{13}$

\begin{tabular}{|c|c|c|}
\hline Verici & $\begin{array}{c}\text { Bağlam (Gönderge) } \\
\text { Bildiri } \\
\text { Kanal (Oluk) } \\
\text { Kod }\end{array}$ & Alic1 \\
\hline
\end{tabular}

Yukarıdaki tabloda da görüldüğü üzere iletişimin gerçekleşebilmesi için verici ve alıcı konumundaki iki kişi şarttır. Bu iki kişinin iletişimi gerçekleştirebilmesi için fizikî bir kanala, kullanacakları iletişim dizgilerine yani koda ve bu

11 Akar, a.g.m., s. 11-12.

12 Rüştü Erata, Sachmalama Türkçe de neymiş!, İstanbul, Yap1 Yayın, 2004, s. 11.

13 Doğan Günay, Dil ve İletişim, İstanbul, Papatya Yayıncılık, 2013, s. 54. 
iletişimde ne açıklandığını ifade eden bir göndergeye gereksinimleri olacaktır. Bu bakımdan yukarıdaki tablo yenide yorumlandığında şu sonuca ulaşılacaktır:

\begin{tabular}{|c|c|c|}
\hline Konuşan Kişi & $\begin{array}{l}\text { Dış Gerçek (Bağlam) } \\
\text { Bildiri } \\
\text { Fiziksel Destek } \\
\text { Kurallar Bütünü (Kod) }\end{array}$ & Dinleyici \\
\hline
\end{tabular}

İletişimin kişinin kendisiyle iletişimi, kişiler arası iletişim ve kitle iletişim şeklindeki farklı etkileşim durumlarından günümüzde en çok başvurulanı kitle iletişimidir. ${ }^{14}$ Bugün tüm dünyada olduğu gibi ülkemizde de kitle iletişim araçlarından en yaygını televizyondur. $\mathrm{Bu}$ aracın gündem yaratma ve yönlendirme noktasında etkisinin en yoğun hissedildiği mevzu ise dil kullanımıdır. ${ }^{15}$ Televizyonun kültürel doku üzerindeki olumlu-olumsuz etkilerinin yanında ait olduğu toplumun ölçünlü dilini, zaman zaman yanlış kullanımlarla kuşattığı ve bu yanlış kullanımların yayılma hızını arttırdığı ve alanını genişlettiği kaçınılmaz bir gerçektir. Ekranlarda yapılan kişisel bir dil yanlışı, farkında dâhi olunmadan topluma mâl olmakta ve çok kısa bir sürede kitlesel bir dil yanlışı haline gelip dili kendi kurallarına aykırı bir değişime zorlamaktadır. ${ }^{16}$

İnsanlar arası iletişimin, bilgi alışverişinin artan teknolojik aygıtlarla gerçekleştirilmesi yaygınlaştıkça bu durum, beraberinde birtakım olumsuzlukları da sürüklemiştir. Bu araçlar vasıtasıyla kültürel, siyasal ve toplumsal açıdan yaşanan yozlaşma ve kirlenmeler kullanılan dili de etkisi altına almıştır. ${ }^{17}$ Söz gelimi medyanın sadece bir günü mercek altına alınsa bir sözlük dolduracak ölçüde batı kökenli kelime ile karşılaşmak olasıdır. Televizyonun icadıyla birlikte kanal adlarından (Show, Inter Star, Flash vs.) program adlarına kadar (Top Secret, Pop Stop, Top On, First Class, Magazin Forever vs.) her şey İngilizceleşti. Televizyon programlarına çıkan kişiler tarafından "Türkiye'de talkamayan insanlara talkshow yaptırıldiğı sürece ben talkabilen insanları ...” şeklinde cümleler kurulurken reklamlarda "dokunmatik" çamaşır makineleri şeklindeki tanımlamalar kimse tarafından yadırganmayınca peşi sıra "anti-leke”, "şaka-matik", "eko-paket" gibi tanımlamalar kullanılmaya başlandı. "Güncel”in yerini "aktüel” aldı ama

14 Nurçay Türkoğlu, Kitle İletişimi ve Kültür, İstanbul, Naos Yayınları, 2003, s. 26.

15 Nesrin Güllüdağ, "Yazılı ve Görsel Basında Dil Estetiği”, 21. Yüzyılda Eğitim ve Toplum, 1/1, 2012, s. 50.

16 Leyla Karahan, "Radyo ve Televizyon Yayınlarında Yöresel Söyleyiş Sorunu, Radyo ve Televizyon Yayınlarında Türk Dilinin Kullanımı" - Tebliğler, Ankara, 1998, s. 53.

17 Emre Kongar, Yozlaşan Medya ve Yozlaşan Türkçe, İstanbul, Remzi Kitabevi, 2003, s. 219. 
yetmedi; "güncellektüel" şeklinde tuhaf melez yapılar oluşturuldu. ${ }^{18}$ Günümüzde sosyologlar tarafından $\mathrm{Z}$ kuşağı olarak adlandırılan dijital nesil, iletişim aracı olarak durdurulamaz bir hızla gelişmekte olan akıllı telefon vb. araçları tercih etmektedir. Çağın, bireyleri hızlı ve etkileşimsel olmaya zorladığı bir dünyada, bu durumdan dil de fazlasıyla etkilenmektedir. Dolayısıyla sanal ortamda kullanılan Türkçede yazılan kelimelerden sesli harfleri çıkarma, konuşma dilindeki bazı kelimeleri kısaltma ve özellikle yarı Türkçe yarı İngilizce yazılan cümleler Z kuşağ1 arasında giderek yaygınlaşmakta ve düzgün cümle kuranların sayısı her geçen gün azalmaktadır. ${ }^{19} \mathrm{Bu}$ bakımdan sanal ortamda kullanılan dil de günümüzde sıklıkla araştırılan ve tartışılan konulardandır.

Kitle iletişim araçlarında hem kullanılan dilin durumunu ${ }^{20}$ hem de kültürel değerlerin işleniş şekillerini ${ }^{21}$ deşifre etmek maksadıyla yapılmış pek çok çalışma bulunmaktadır. Sözgelimi Demirtaş, "Sanal Ortamdaki Yazışma Dilinin Türkçeye Etkisi Üzerine"22 çalışmasında, Y11maz ise "Internet Ortamında Şekillenen Söyleyişi Dili Üzerine Toplum Dil Bilimsel Bir İnceleme" ${ }^{23}$ çalışmasında konuyu etraflıca incelemişlerdir. Fakat günümüzde hem Türkiye'de hem de diğer dünya ülkelerinde popüler kültürün birinci dereceden aktarıcısı olan ve sayıları (2015 yılında ekrana gelen 8 bin 500 programın \%40'1nı diziler oluşturmaktadır. ${ }^{24}$ ), ta-

18 Feyza Hepçilingirler, Türkçe “Off”, İstanbul, Remzi Kitabevi, 2005, s. 46-47-48.

19 Tüba Karahisar, "Dijital Nesil, Dijital İletişim ve Dijitalleşen (!) Türkçe” Online Academic Journal of Information Technology, 4(12), 2013.

20 Ebru Güzel - Arzu Karakurt, "Dil Yozlaşması ve Söyleyiş Bozukluğu: Televizyon Reklamlar1nın Göstergebilimsel Açıdan Çözümlenmesi”, Balkan ve Yakın Doğu Sosyal Bilimler Dergisi, 2(4), 2016; Nebahat Akgün Çomak, "Kitle İletişim Araçları ve Dil Sorunları Bağlamında Sözcüklerle Yabancılaşma”, Selçuk İletişim, 2(3), 2014.

21 Feyza Akınerdem, "Yerli Dizi Anlatıları ve İzleyici Katılımı: Uçurum Dizisini Ekşisözlük ve Twitter'la Birlikte İzlemek”, Folklor/Edebiyat, 18(72), 2012; Melis Yalçın, "Popüler Kültür Ürünü Olarak Türk TV Dizilerinde Etnografik İletişim Kodlarının Kullanımı: Diriliş Ertuğrul Dizisi Örneği”, Insan ve Toplum Bilimleri Araştırmaları Dergisi, 5(7), 2016; M. Çağlar Kurtdaş, "Jean Baudrilliard'ın Simülasyon Kuramında Kitle İletişim Araçları ve Toplumsalın Sorunu, Hitit Üniversitesi Sosyal Bilimler Enstitüsü Dergisi, 11(3), 2018, s. 2012-2023.

22 Ahmet Demirtaş, "Sanal Ortamdaki Yazışma Dilinin Türkçeye Etkisi Üzerine”, International Human and Civillization Congress from Past to Future Kongresi Kongre Kitabı (387-394), Alanya, 2019.

23 Mehmet Fatih Y1lmaz, "İnternet Ortamında Şekillenen Söyleşi Dili Üzerine Toplum Dil Bilimsel Bir İnceleme”, Dede Korkut Dergisi, 1(1), 2012.

24 Muhammet Faruk Bayram, “Türkiye'de Sahte İhtiyacın Kaynağı Olarak Dizi Filmler”, (Yayımlanmamış Yüksek Lisans Tezi), Hacettepe üniversitesi Sosyal Bilimler Enstitüsü, Ankara, 2018, s. 57. 
kipçileri her geçen gün artan televizyon dizilerinin adları üzerine yapılan çalışmalar sinırlı düzeydedir. ${ }^{25}$

Bu çalışmada dizi adları örnekleminden Türkçenin bugünkü durumuyla ilgili bilgi edinebilmek maksadıyla aşağıdaki sorulara yanıt aranmıştır:

1. Dizi adlarında kullanılan Türkçenin etkileşim yaşadı̆̆ı diller hangileridir?

2. Dizi adlarında kullanılan Türkçenin etkileşim yaşadı̆̆ı diller ile durumu, Türk dil/kültür tarihine uygunluk göstermekte midir?

3. Günümüzde sanal ortamdaki yazışma dilinde hâkim kaynak dil konumunda olan Batı dillerinin ve özellikle İngilizcenin dizi adlarındaki durumu nedir?

\section{Yöntem}

\section{Araştırmanın Modeli}

Nitel araştırma deseninden durum çalışmasına uygun olarak hazırlanan bu çalışmadaki amaç, televizyon dizi adlarının söz varlığını oluşturan kelimelerin kökenleri bakımından tahlil ve tasnifini yapmaktır. Örnek olay incelemesi ya da vaka çalışması gibi farklı adları da bulunan durum çalışması, herhangi bir durumun derinlemesine araştırılıp betimlenmesi şeklinde tanımlanabilir. ${ }^{26}$ Durum çalışması; nasıl ve niçin sorularının hâkim olduğu araştırmada, araştırmacının ya hiç ya da çok az etkisiyle olayın doğal sınırları içinde değerlendirilmesidir. Durum çalışmasının bütüncül tek durum, bütüncül çoklu durum, iç içe geçmiş tek durum, iç içe geçmiş çoklu durum olmak üzere farklı desenleri bulunmaktadır. ${ }^{27}$ $\mathrm{Bu}$ çalışmanın temellendirildiği iç içe geçmiş tek durum deseni ise tek bir durumun birden fazla analiz birimiyle ve bütüncül bir bakış açısıyla incelenmesidir. ${ }^{28}$ $\mathrm{Bu}$ yolla elde edilen veriler, kategorisel içerik analizi ile belirli konu başlıkları altında tasniflenmiş ve tasniflerin oluşturduğu nicel veriler, betimsel istatistiksel analiz ile yeniden yorumlanmıştır. Dolayısıyla çalışma, nitel ve nicel yöntemlerin beraber kullanıldığı bir mecrada değerlendirilmiştir.

25 Yakup Yılmaz - Emre Özkurt, “Türkiye'de TV Program Adlarında Türkçeye Uygunluk”, Rumelide, 7/1, 2016.

26 Münevver Subaşı - Kübra Okumuş, "Bir Araştırma Yöntemi Olarak Durum Çalışması”, Atatürk Üniversitesi Sosyal Bilimler Enstitüsü Dergisi, 21(2), 2017, s. 425.

27 Robert K. Yin, "Case Study Research Design and Methods", 3. bs., London, Sage Publications, 2003, s. 39-40.

28 Berrak Aytaçlı, "Durum Çalışmasına Ayrıntılı Bir Bakış”, Adnan Menderes Üniversitesi Eğitim Fakültesi Eğitim Bilimleri Dergisi, 3(1), 2012, s. 7. 


\section{Araştırma İnceleme Nesneleri}

Bu çalışmada Türkiye'de en çok izlenen 7 televizyon kanalının internet sitelerinden toplam 576 dizi adı derlenmiştir. Veri havuzu oluşturulurken ATV'den 80 dizi adı, Fox'tan 90 dizi adı, Kanal D'den 99 dizi adı, Kanal 7'den 44 dizi adı, Show TV'den 79 dizi adı, Star'dan 97 dizi adı ve TRT 1'den 87 dizi adı tespit edilmiştir

Araştırmanın inceleme nesnelerini oluşturan dizi adları aşağıdaki tabloda gösterilmiştir:

Tablo 1. Reyting Bazında En Çok İzlenen Televizyon Kanallarında Yayınlanan Diziler

\begin{tabular}{|c|c|}
\hline Kanal Adı & Dizi Adları \\
\hline ATV & $\begin{array}{l}\text { Adanalı (1/1), Affedilmeyen (1/2), Affet Bizi Hocam (1/3), } \\
\text { Ah İstanbul (1/4), Aile Saadeti (1/5), Aliye (1/6), Al Yazmalım } \\
\text { (1/7), Aman Annem Görmesin (1/8), Asmalı Konak (1/9), Aşk } \\
\text { Oyunu (1/10), Aşk ve Mavi (1/11), Aşka Sürgün (1/12), Avru- } \\
\text { pa Yakası (1/13), Azap Yolu (1/14), Baba Evi (1/15), Bebeğim } \\
\text { (1/16), Belalı Baldız (1/17), Beni Bırakma (1/18), Beyaz Gelin- } \\
\text { cik (1/19) Bir Demet Tiyatro (1/20), Bir İstanbul Masalı (1/21), } \\
\text { Bizim Evin Halleri (1/22), Bugünün Saraylısı (1/23), Büyük } \\
\text { Yalan (1/24), Canevim (1/25), Canım Ailem (1/26), Cennetin } \\
\text { Çocukları (1/27), Çiçek Taksi (1/28), Deli Yürek (1/29), Dicle } \\
\text { (1/30), Duvar (1/31), El Gibi (1/32), Eşkıya Dünyaya Hüküm- } \\
\text { dar Olmaz (1/33), Ey Aşk Nerdesin (1/34), Ezel (1/ 35), Gazi } \\
\text { (1/36), Gönülçelen (1/37), Görgüsüzler (1/38), Hatırla Sevgili } \\
\text { (1/39), Hayal Ve Gerçek (1/40), Hepsi 1 (1/41), Hercai (1/42), } \\
\text { İki Yabancı (1/43), İkinci Bahar (1/44), Kaçak (1/45), Kanatsız } \\
\text { Kuşlar (1/46), Karadayı (1/47), Karayılan (1/48), Kelebek Çık- } \\
\text { mazı (1/49), Kertenkele (1/50), Kelebekler (1/51), Kız Kaçıran } \\
\text { (1/52), Kimse Bilmez (1/53), Komiser Nevzat (1/54), Korku- } \\
\text { suzlar (1/55), Kuruluş Osman (1/56), Kuş Dili (1/57), Limon } \\
\text { Ağacı (1/58), Mahallenin Muhtarları (1/59), Mahşer (1/60), Par- } \\
\text { maklıklar Ardında (1/61), Selena (1/62), Sen Anlat Karadeniz } \\
\text { (1/63), Senden Başka (1/64), Servet Avcısı (1/65), Sessiz Ge- } \\
\text { miler (1/66), Sıcak Saatler (1/67), Sıla (1/68), Sinekli Bakkal } \\
\text { (1/69), Süper Baba (1/70), Şahin Tepesi (1/71), Şöhret (1/72), } \\
\text { Talih Kuşu (1/73), Tatar Ramazan (1/74), Unutulmaz (1/75), Ya- } \\
\text { ban Gülü (1/76), Yalancısın Sen (1/77), Yersiz Yurtsuz (1/78), } \\
\text { Zengin ve Yoksul (1/79), Zerda (1/80). }\end{array}$ \\
\hline
\end{tabular}


4N1K İlk Aşk (2/1), Adı Mutluluk (2/2), Adı: Zehra (2/3), Ali Ayşe'yi Seviyor (2/4), Araf Zamanı (2/5), Arka Siradakiler Umut (2/6), Asayiş Berkemal (2/7), Aşk Yalanı Sever (2/8), Aşk Yeniden (2/9), Aşkın Halleri (2/10), Babam İçin (2/11), Babam Sinıfta Kaldı (2/12), Bana Sevmeyi Anlat (2/13), Benim Hala Umudum Var (2/14), Bir Aile Hikâyesi (2/15), Bir Aşk Hikayesi (2/16), Bir Deli Rüzgar (2/17), Bir Ferhat ile Şirin Hikayesi (2/18), Bir Mucize Olsun (2/19), Bizim Hikaye (2/20), Bu Sayılmaz (2/21), Canan (2/22), Canım Benim (2/23), Çak1l Taşları (2/24), Çifte Saadet (2/25), Çoban Yıldızı $(2 / 26)$, Çocuklar Duymasın (2/27), Dayan Yüreğim (2/28), Dedemin Dolabı (2/29), Deli Gönül (2/30), Deniz Yıldızı (2/31), Derin Sular (2/32), Dinle Sevgili (2/33), Doktorlar (2/34), Düşler ve Umutlar (2/35), Emanet (2/36), Esaretim Sensin (2/37), Familya (2/38), Fatih Harbiye (2/39), Ferhat İle Şirin (2/40), Görüş Günü Kadınları (2/41), Günahkar (2/42), Harem (2/43), Hayat FOX Sevince Güzel (2/44), Her Yerde Sen (2/45), Hindistan'da Aşk (2/46), İnadına Aşk (2/47), Kadın (2/48), Kadim Dostum (2/49), Kahireli Palas (2/50), Kalbim Yangın Yeri (2/51), Kalbimdeki Deniz (2/52), Karagül (2/53), Karamın Dediği Dedik Çaldığ1 Kontrbas (2/54), Kayıtdışı (2/55), Kırlangıç Fırtınası (2/56), Kiraz Mevsimi (2/57), Kirli Beyaz (2/58), Kocamın Ailesi (2/59), Komşular (2/60), Kördüğüm (2/61), Kurşun (2/62), Lale Devri (2/63), Melekler Korusun (2/64), Merhaba Hayat (2/65), Mucize Doktor (2/66), Muhteşem Yüzyıl Kösem (2/67), N'olur Ayrıla$\lim (2 / 68)$, Nerdesin Birader (2/69), No:309 (2/70), Not Defteri (2/71), O Hayat Benim (2/72), Öğretmen Kemal (2/73), Ömre Bedel (2/74), Ruhumun Aynası (2/75), Rüzgarın Kalbi (2/76), Sana Bir Sır Vereceğim (2/77), Savaşçı (2/78), Sen Benimsin (2/79), Sensiz Yaşayamam (2/80), Şehrin Melekleri (2/81), Şen Yuva (2/82), Şevkat Yerimdar (2/83), Umuda Kelepçe Vurulmaz (2/84), Umutsuz Ev Kadınları (2/85), Vurgun (2/86), Yasak Elma (2/87), Yer Gök Aşk (2/88), Zehirli Sarmaş1k (2/89), Zengin Kız Fakir Oğlan (2/90). 
Adı Efsane (3/1), Akasya Durağı (3/2), Alın Yazım (3/3), Altın Soylar (3/4), Analı Oğullu (3/5), Ankara'nın Dikmeni (3/6), A.Ş.K. (3/7), Annem Uyurken (3/8), Aş̧-1 Memnu (3/9), Aşk ve Gurur (3/10), Aşk ve Günah (3/11), Babam ve Ailesi (3/12), Bana Artık Hicran De (3/13), Benim Adım Gültepe (3/14), Beş Kardeş (3/15), Bir Bulut Olsam (3/16), Bir Çocuk Sevdim (3/17), Bir Deniz Hikâyesi (3/18), Bir Litre Gözyaş1 (3/19), Bir Umut Yeter (3/20), Bizim Yenge (3/21), Bodrum Masalı (3/22), Boynu Bükükler (3/23), Cinayet (3/24), Cumaya Kalsa (3/25), Çalıkuşu (3/26), Çocuklar Duymasın (3/27), Dostlar Mahallesi (3/28), Evlat Kokusu (3/29), Fatih (3/30), Fatmagül'ün Suçu Ne? (3/31), Gece Gündüz (3/32), Geniş Aile (3/33), Gülizar (3/34), Güllerin Savaşı (3/35), Güneşi Beklerken (3/36), Güneş'in Kızları (3/37), Güzel Çirkin (3/38), Hanımın Çiftliği (3/39), Hayatımın Aşkı (3/40), Hayat Mucizelere Gebe (3/41), Hayati ve Diğerleri (3/42), Hayat Şarkısı (3/43), Hıçkırık (3/44), İki Yalancı (3/45), İkizler Memo-Can (3/46), İnadına Yaşamak KANAL D (3/47), İnsanlık Suçu (3/48), İntikam (3/49), İsimsizler (3/50), Kanıt (3/51), Kanıt: Ateş Üstünde (3/52), Kalbim Ege'de Kaldı (3/53), Kara Kutu (3/54), Kara Yazı (3/55), Kayıp (3/56), Kayıp Şehir (3/57), Keşanlı Ali Destanı (3/58), Kızlarım İçin (3/59), Koca Koca Yalanlar (3/60), Kötü Yol (3/61), Kurtlar Vadisi Pusu (3/62), Kuzey Güney (3/63), Küçük Ağa (3/64), Küçük Kadinlar (3/65), Küçük Sirlar (3/66), Leke (3/67), Masum (3/68), Mehmed: Bir Cihan Fatihi (3/69), Merhamet (3/70), Meryem (3/71), Muhteşem İkili (3/72), Mükemmel Çift (3/73), Ne Diyorsun? (3/74), Nuri (3/75), Öyle Bir Geçer Zaman ki (3/76), Poyraz Karayel (3/77), Sevdanın Bahçesi (3/78), Siyah Beyaz Aşk (3/79), Sultan (3/80), Şeref Meselesi (3/81), Şüphe (3/82), Tatlı İntikam (3/83), Tutsak (3/84), Türkan (3/85), Ulan İstanbul (3/86), Umutsuz Ev Kadınları (3/87), Urfalıyam Ezelden (3/88), Üsküdar'a Giderken (3/89), Vatanım Sensin (3/90), Veda (3/91), Ver Elini Aşk (3/92), Vicdan (3/93), Yalan Dünya (3/94), Yaz’ın Öyküsü (3/95), Yıllar Sonra (3/96), Yol Arkadaşım (3/97), Yüzleşme (3/98), Zeytin Tepesi (3/99). 
Acı Hayat (4/1), Adını Feriha Koydum (4/2), Ah Kalbim (4/3), Aklın Başına Gelsin (4/4), Aliye (4/5), Benimsin (4/6), Bıçak Sirtı (4/7), Bir Garip Aşk (4/8), Bir Tutam Aşk (4/9), Büyük Yalan (4/10), Canım Ailem (4/11), Deli Divane (4/12), Deli Yürek (4/13), Doktorlar (4/14), Elif (4/15), Ekmek Teknesi (4/16), Feda (4/17), Hayatın Kiyısında (4/18), Hz. Meryem (4/19), Hz.

KANAL 7 Ömer (4/20), Hz. Yusuf (4/21), İkimizin Yerine (4/22), İki Yabancı (4/23), İstanbul Hatırası (4/24), İşgal (4/25), Kayıp Hayatlar (4/26), Kız Annesi (4/27), Kobra Takibi (4/28), Kördüğüm (4/29), Kurtlar Vadisi (4/30), Müziklerin Efendisi (4/31), Ömre Bedel (4/32), Sarı Sarı Liralar (4/33), Sensiz Olmaz (4/34), Sev Beni (4/35), Sevda Masalı (4/36), Sev Yeter (4/37), Sil Baştan (4/38), Sonsuza Dek (4/39), Yabanc1 Damat (4/40), Yemin (4/41), Yer Gök Aşk (4/42), Yol (4/43), Zerda (4/44).

Acı Aşk (5/1), Acil Aşk (5/2), Adını Feriha Koydum (5/3), Acil Servis (5/4), Adını Kalbime Yazdım (5/5), Ağlatan Dans (5/6), Ah Neriman (5/7), Altın Dağlı (5/8), Analı Oğullu (5/9), Arkadaşlar İyidir (5/10), Asla Vazgeçmem (5/11), Aşk Ağlatır (5/12), Aşk Ekmek Hayaller (5/13), Aşk ve Gurur (5/14), Balkan Dügünü (5/15), Bebek İşi (5/16), Beni Affet (5/17), Benim İçin Üzülme (5/18), Beyaz Yalan (5/19), Bir Deli Sevda (5/20), Canım Babam (5/21), Cesur Yürek (5/22), Çarpışma (5/23), Çukur (5/24), Deli Saraylı (5/25), Deniz Yıldızı (5/26), Dila Hanım (5/27), Dudaktan Kalbe (5/28), Düşman Kardeşler (5/29), Emir'in Yolu (5/30), Es Es (5/31), Eve Düşen Yıldırım (5/32), Ezel (5/33), Ezra (5/34), Fabrika K1z1 (5/35), Firuze (5/36), Gamsiz Hayat (5/37), Gece SHOW TV Sesleri (5/38), Gönül Ferman Dinlemiyor (5/39), Gülperi (5/40), Gülümse Yeter (5/41), Gün Akşam Oldu (5/42), İlişki Durumu: Evli (5/43), İlişki Durumu: Karışık (5/44), İçerde (5/45), İstanbul Sokakları (5/46), Kalp Atışı (5/47), Kahramanlar (5/48), Karadağlar (5/49), Karakol (5/50), Klavye Delikanlıları (5/51), Kuzey Yıldızı: İlk Aşk (5/52), Kurtlar Vadisi Pusu (5/53), Lale Devri (5/54), Manyak Dükkan (5/55), Mayıs Kraliçesi (5/56), Mihrap Yerinde (5/57), Melekler (5/58), Muhteşem Yüzyıl (5/59), Ne Münasebet (5/60), Nöbet (5/61), Oldu Teşekkürler (5/62), Otel Divane (5/63), Oyunbozan (5/64), Önce Vatan (5/65), Pis Yedili (5/66), Salih Kuşu (5/67), Servet (5/68), Sensiz Olmaz (5/69), Sevdaluk (5/70), Sinıf (5/71), Suskunlar (5/72), Türk Malı (5/73), Ustura Kemal (5/74), Yeni Gelin (5/75), Yılanların Öcü (5/76), Yuvamdaki Düşman (5/77), Yüz (5/78), Zemheri (5/79). 
Acayip Hikayeler (6/1), Adını Sen Koy (6/2), Aile Reisi (6/3), Akasya Durağı (6/4), Anne (6/5), Anneler ve Kızları (6/6), Aşkın Bedeli (6/7), Aşktan Kaçılmaz (6/8), Ateş Böceği (6/9), Ateşe Yürümek (6/10), Avlu (6/11), Ay Işığı (6/12), Ay Tutulması (6/13), Baba Ocağı (6/14), Babamın Günahları (6/15), Babalar ve Evlatlar (6/16), Behzat Ç. (6/17), Beni Affet (6/ 18), Benim Annem Bir Melek (6/19), Benim Hala Umudum Var (6/20), Benim Tatlı Yalanım (6/21), Ben de Özledim (6/22), Bir Çocuk Sevdim (6/23), Bir Erkek Bir Kadın (6/24), Bir Ömür Yetmez (6/25), Börü (6/26), Canımın İçi (6/27), Cennetin Sırları (6/28), Cesur Ve Güzel (6/29), Çember (6/30), Çilek Kokusu (6/31), Çocuk (6/32), Deniz Kızı (6/33), Dila Hanım (6/34), Dolunay (6/35), Düriye'nin Güğümleri (6/36), Erkenci Kuş (6/37), Evlerden Biri (6/38), Fazilet Hanım ve Kızları (6/39), Firar (6/40), Gecenin Kraliçesi (6/41), Geniş Aile (6/42), Göç Zamanı (6/43), Gönül İşleri (6/44), Güvercin (6/45), Güzel Köylü (6/46), Hanım Köylü (6/47), Hatırla Sevgili (6/48), Hayat Bazen Tatlıdır STAR (6/49), Hayat Sırları (6/50), İbreti Alem (6/51), İçimdeki Fırtına (6/52), İffet (6/53), İhanet (6/54), İstanbul'un Çocukları (6/55), İstanbullu Gelin (6/56), İşler Güçler (6/57), Jest Sosyete (6/58), Kaçak Gelinler (6/59), Kaderimin Yazıldığı Gün (6/60), Kalbim Dört Mevsim (6/61), Kalbimin Sultanı (6/62), Kara Sevda (6/63), Kardeş Çocukları (6/64), Kardeş Payı (6/65), Kiralık Aşk (6/66), Koyu Kırmızı (6/67), Kurt Seyit ve Şura (6/68), Kurtlar Vadisi Pusu (6/69), Kuzgun (6/70), Küçük Hesaplar (6/71), Küçük Kadınlar (6/72), Küçük Sırlar (6/73), Kül ve Ateş (6/74), Makber (6/75), Medcezir (6/76), Muhteşem Yüzyıl (6/77), Nefes Nefese (6/78), Papatya (6/79), Paramparça (6/80), Sefirin Kızı (6/81), Serçe Saray (6/82), Sevdim Seni Bir Kere (6/83), Sevgili Geçmiş (6/84), Surat (6/85), Sihirli Annem (6/86), Siyah İnci (6/87), Sudan Bıkmış Balıklar (6/88), Sonbahar (6/89), Şahane Damat (6/90), Tatlı Küçük Yalancılar (6/91), Ufak Tefek Cinayetler (6/92), Urfalıyam Ezelden (6/93), Yalanc1 Bahar (6/94), Yıldızlar Şahidim (6/95), Yol Arkadaşım (6/96), Yüksek Sosyete (6/97). 
6 Mant1 (7/1), Abur Cubur (7/2), Acemi Müezzin (7/3), Adım Bayram Bayram (7/4), Adını Sen Koy (7/5), Ah Kalbim (7/6), Alayına İsyan (7/7), Aşkın Kanunu (7/8), Avrupa Avrupa (7/9) Aynadaki Düşman (7/10), Ayrılık (7/11), Baba Candır (7/12), Başrolde Aşk (7/13), Beni Böyle Sev (7/14), Bir Yastıkta (7/15), Bir Yusuf Masalı (7/16), Bir Zamanlar Osmanlı (7/17), Böyle Bitmesin (7/18), Bulutların Ötesi (7/19), Büyük Sürgün Kafkasya (7/20), Cam Kırıkları (7/21), Canını Sevdiğim İstanbul'u (7/22), Çılgın Kanal (7/23), Çocukluk Günleri (7/24), Diriliş: Ertuğrul (7/25), Elde Var Hayat (7/26), En Uzun Yüzyıl (7/27), Esir Sultan (7/28), Eski Hikaye (7/29), Evvel Zaman Hikayesi (7/30), Gökkuşağı Çocukları (7/31), Gönül Hırsızı (7/32), Gurbette Aşk (7/33), Halil İbrahim Sofrası (7/34), Halka (7/35), Hangimiz Sevmedik (7/36), Hanımeli Sokağ (7/37), Hayat Ağac1 (7/38), Hayata Beş Kala (7/39), Heradot Cevdet (7/40), Hesaplaşma (7/41), Hicran Yarası (7/42), İstanbul'da Aşı1k Oldum TRT 1 (7/43), Karş1 Köyün Delisi (7/44), Kaybedenler (7/45), Kayıp Aranıyor (7/46), Kizıl Elma (7/47), Komiser Rex (7/48), Korkma (7/49), Kurt Kanunu (7/50), Küçük Hanımefendi (7/51), Küstüm Çiçeği (7/52), Leyla ile Mecnun (7/53), Lise Devriyesi (7/54), Mavi Kelebekler (7/55), Mazi Kalbimde Yaradır (7/56), Mehmetçik Kut'ül Amare (7/57), Milat (7/58), Mor Menekşeler (7/59), Osmanlı Tokadı (7/60), Prensin Şarkısı (7/61), Sakarya Firat (7/62), Sarayın İncisi (7/63), Seddülbahir 32 Saat (7/64), Seksenler (7/65), Sende Gitme (7/66), Sevda Kuşun Kanadında (7/67), Sinıf (7/68), Son Çıkış (7/69), Son Destan (7/70), Sudan Sebepler(7/71), Şimdi Onlar Düşünsün (7/72), Şubat (7/73), Tacir (7/74), Tek Yürek (7/75), Yalaza (7/76), Yamak Ahmet (7/77), Yapma Diyorum (7/78), Yedi Güzel Adam (7/79), Yedikule Hayat Yokuşu (7/80) Yeniden Başla (7/81), Yerden Yüksek (7/82), Yeşil Deniz (7/83), Yol Ayrımı (7/84), Yunus Emre Aşkın Yolculuğu (7/85), Zengin Kız Fakir Oğlan (7/86), Zoraki Başkan (7/87).

\section{Verilerin Toplanması ve Analizi}

Veriler, doküman incelemesi yöntemiyle toplanmıştır. Doküman incelemesi, değerlendirilecek durum veya durumlar ile ilgili bilgi içeren yazılı materyallerin analizinden oluşmaktadır. ${ }^{29}$ Verilerin anlamlandırılması aşamasında ise içerik

29 Ali Yıldırım - Hasan Şimşek, Sosyal Bilimlerde Nitel Araştırma Yöntemleri, Ankara, Seçkin, 2003, s. 217. 
analizi kullanılmıştır. İçerik analizi, nitel veri analiz türlerinden en sık başvurulan yöntemdir ve daha çok yazılı/görsel verilerin analizinde kullanılmaktadır. Bu yöntemde araştırmacı tümdengelimci bir yaklaşımla araştırma konusu ile ilgili kategoriler geliştirmektedir. Kategoriler geliştirilirken benzer bir çalışma yürütmeyi planlayan başka araştırmacıların da aynı sonuçlara ulaşabileceği şekilde bir yaklaşım içinde olunmalıdır. ${ }^{30}$

Araştırma için kanalların ilgili internet sitelerinden derlenen dizi adlarındaki kelimelerin hangi kanala ve diziye ait olduğunu belirlemek maksadıyla televizyon kanalları ve her kanala ait dizi adları kendi içinde alfabetik bir şekilde sıralanmış ve madde başı anlamlı ya da görevli her bir kelime, kanalın alfabetik sırasına ve ait olduğu kanaldaki kendi alfabetik sıra numarasına göre kodlanmıştır: 1/69 kodlu kelime ATV'de 69. sıradaki dizi adında yer alırken 7/37 kodlu kelime ise TRT 1'de 37. sıradaki dizi adında yer almaktadır. Dizi adlarındaki tüm kelimeler, bu şekilde kodlanarak 1287 kelimelik bir havuz oluşturulmuştur. Elde edilen 1287 kelimelik veri, öncelikle kökenleri bakımından tasniflenmiştir. Sonrasında her kategoride toplanan kelimelerin kodlarından yola çıkarak bu kelimelerin hangi kanaldaki hangi diziye ait olduğu tespit edilmiş ve ulaşılan sayısal verilerle çeşitli istatistiksel grafikler oluşturabilme imkânı sağlanmıştır. Ayrıca her kategorideki kelimelerin sıklıkları da tespit edilerek köken itibarıyla yoğunluğun hangi kategoride olduğu tespit edilmeye çalışılmıştır.

Öte yandan bulgular kısmındaki tasniflere geçmeden önce aydınlatılmaya muhtaç bir husus da Türkçe kökenli kelimeler dışında özellikle Arapça, Farsça, Fransızca, Rumca vb. kökenli kelimelerin Türkçenin söz varlığı içindeki durumuyla ilgili mevzudur. Aşağıdaki tasniflerde de görüleceği üzere dilimizde yüzyıllardır var olan bu kelimelerin neredeyse tamamına yakınının Türkçe karşılıklarının bulunmadığını söyleyebiliriz yahut bulunmuş olsa da kabul görmediği için dile yerleşmemiş olduğunu ifade etmek mümkündür. Neticede bu kelimeler, kaynak dillerden Türkçeye girmiş; büyük/küçük ses veya şekil değişiklikleri hatta yüklenilen yeni anlamlarla benimsenip kullanılagelmiştir. Dolayısıyla ilk bakışta Türkçe kökenli olmadıkları dahi anlaşılamayan bu kelimeleri, yabancı kelime olarak görmek doğru olmayacağı için en azından Türkçeleşmiş alıntı kelime olarak değerlendirmek daha doğru olacaktır. ${ }^{31}$

30 David Silverman, Interpreting Qualitative Data: Methods for Analysing Talk, Text and Interaction, London, Sage Publication, 2001.

31 Yasemin Yıldız, "Türkçe Bitki Adlarının Anlam Bilimi Açısından İncelenmesi”, (Yayımlanmamış Doktora Tezi), Sakarya Üniversitesi Sosyal Bilimler Enstitüsü, Sakarya, 2020, s. 7. 


\section{Bulgular}

Araştırma bulguları, televizyon dizi adlarında kullanılan kelimelerin kökenleri bakımından sınıflandırılması neticesinde oluşan üç temel kategoriden ve bu kategorilere bağlı alt kategorilerden oluşmaktadır.

\section{1. İçerisinde Türkçe Kökenli Kelimelerin Yer Aldığı Söz Varlığı}

$\mathrm{Bu}$ kategoride, dizi adlarında yer alan madde başı her bir kelime Türkçe, Türkçe ve Türkçe, Türkçe ve alıntı kelime ile alıntı kelime ve Türkçe olma durumlarına göre farklı başlıklar altında tasniflenmiştir.

\subsection{Türkçe Söz Varlığı}

Aşağıda madde başı olan Türkçe kelimeler, tüm dizi adlarında kullanıldığı yerlerin kodları ile birlikte listelenmiştir.

1 (1/14), 6 (7/1), 32 (7/64), 309 (2/70), 4N1K (2/1), ac1 (4/1, 5/1), ad (2/2, 2/3, $3 / 1,3 / 13,3 / 14,5 / 5,7 / 4)$, adım (7/4), ağa (3/64), ağaç (1/58, 7/38), ağlat- (5/12), ağlat- (5/6), ah (1/4, 4/3, 5/7, 7/6), al (1/7), alay1 (7/7), altın (3/4), anlat- $(1 / 63,2 / 13)$, anne $(1 / 8,3 / 8,4 / 276 / 5,6 / 6,6 / 19,6 / 86)$, aran- (7/46), arka (2/6), arkadaş (3/97, 5/10 6/96), art (1/61), art1k (3/13), asmal1 (1/9), avc1 (1/65), ay (6/12), ayril- (2/68), ayrilık (7/11), ayrım (7/84), baba (1/15, 1/70, 2/11, 2/12, 3/12, 5/21, 6/14, 6/15, 6/16, 7/12), baldız (1/17), balık (6/88), başka (1/64), başkan (7/87), başla- (7/81), baştan (4/38), bebek $(1 / 16,5 / 16)$, bekle- $(3 / 36)$, ben $(1 / 18,1 / 63,1 / 64,1 / 77,2 / 13,2 / 14$, 2/23, 2/72, 2/79, 3/12, 3/13, 3/14, 4/6, 4/35, 5/17, 5/18, 6/18, 6/19, 6/20, 6/21, 6/22, 7/14), beş (3/15, 7/39), bik- (6/88), birakma- (1/18), bilme- (1/53), bir (1/20,1/21, $1 / 41,2 / 15,2 / 16,2 / 17,2 / 18,2 / 19,2 / 77,3 / 15,3 / 16,3 / 17,3 / 18,3 / 20,3 / 69,3 / 76,4 / 8$, $4 / 9,5 / 20,6 / 19,6 / 23,6 / 24,6 / 25,6 / 83,7 / 15,7 / 16,7 / 17)$, biri (6/38), bitme- (7/18), biz (1/3, 1/22, 2/20,3/21), böcek (6/9), börü (6/26), böyle (7/14, 7/18), bu (2/21), bulut (3/16, 7/19), büyük $(1 / 24,4 / 10,7 / 20)$, çakıl (2/24), çal- (2/54), çarpış- $(5 / 23)$, çıkış (7/69), çıkma- (1/49), çılgın $(7 / 23)$, çiçek $(1 / 28,1 / 51)$, çilek $(6 / 31)$, çocuk (1/27, 2/27, 3/17, 3/27, 6/23, 6/32, 6/55, 6/64, 7/31), çocukluk (7/24), çukur (5/24), dayan- $(2 / 28)$, de- $(2 / 54,3 / 13,3 / 74,7 / 78)$, de $(6 / 22,7 / 66)$, dede $(2 / 29)$, dek $(4 / 39)$, deli $(1 / 29,2 / 17,2 / 30,4 / 13,5 / 20,5 / 25,7 / 44)$, Deniz (3/18), deniz $(2 / 52,7 / 83)$, derin (2/32), Dicle (1/30), Dikmen (3/6), dinle- (2/33), diril- (7/25), dört (6/61), dudak $(5 / 28)$, durak $(3 / 2,6 / 4)$, durum $(5 / 43,5 / 44)$, duyma- $(2 / 27,3 / 27)$, düğün $(5 / 15)$, düş (2/35), düşün- (7/72), ekmek $(4 / 16,5 / 13)$, el $(1 / 32,3 / 92,7 / 26)$, elma $(2 / 87$, 7/47), en (7/27), erkek (6/24), erkenci (6/37), eski (7/29), ev (1/15, 1/22, 2/85, 3/87, $5 / 32,6 / 38)$, evli $(5 / 43)$, ey $(1 / 34)$, gebe $(3 / 41)$, gece $(6 / 41)$, geç- $(3 / 76)$, geçmiş $(6 / 84)$, gelin $(5 / 75,6 / 56,6 / 59)$, gelincik $(1 / 19)$, gemi $(1 / 66)$, geniş $(3 / 33,6 / 42)$, Gerçek (1/40), gibi (1/32), git- (3/89), gitme- (7/66), göç (6/43), gönül (2/30, 5/39, 
6/44, 7/32), gör- (2/41), görgüsüz (1/38), görme- (1/8), gülümse- (5/41), gün (2/41, $5 / 42,6 / 60,7 / 24)$, güneş (3/36), Güneş (3/37), Güney (3/63), güvercin $(6 / 45)$, güzel $(2 / 44,6 / 29,6 / 46,7 / 79)$, hangi (7/36), hanım $(3 / 39,5 / 27,6 / 34,6 / 39,6 / 47)$, hepsi (1/41), hıçkırık (3/44), hırsız (7/32), 1şık (6/12), iç $(6 / 27,6 / 52)$, içeri $(5 / 45)$, için $(2 / 11,3 / 59,5 / 18)$, iki $(1 / 43,3 / 45,4 / 23)$, ikili (3/72), ikimiz (4/22), ikinci (1/44), ikizler (3/46), ile $(2 / 18,2 / 40,7 / 53)$, ilişki $(5 / 43,5 / 44)$, ilk $(2 / 1,5 / 52)$, inci $(6 / 87$, $7 / 63)$, insanlık (3/48), ipucu (3/61), iş (5/16, 6/44), işler güçler (6/57), iyi $(5 / 10)$, kaçak (1/45, 6/59), kaçılma- (6/8), kadın (2/41, 2/48, 2/85, 3/65, 3/87, 6/24, 6/72), kal- $(3 / 25,3 / 53,7 / 39)$, kanat (7/67), kanatsiz (1/46), kanit (3/51, 3/52), kara (3/54, 3/55, 6/63), kardeş (3/15, 5/29, 6/64, 6/65), karı (2/54), karışık (5/44), karş1 (7/44), kelebek $(1 / 49,1 / 51,7 / 55)$, Kertenkele (1/50), kırgın (1/50), kırık (7/21), kırlangıç (2/56), k1y1 (4/18), k1z (2/90, 3/37, 3/59, 4/27, 5/35, 6/6, 6/39, 6/81, 7/86), k1z1l (7/47), kimse (1/53), kiralık (6/66), kirli (2/58), koca (2/59), koku $(3 / 29,6 / 31)$, komşu (2/60), konak (1/9), korkusuz (1/55), korkma- (7/49), koru- (2/64), koyu (6/67), Kösem (2/67), kötü (3/61), kurşun (2/62), kurt (3/62, 4/30, 5/53, 6/68, 6/69, $7 / 50)$, kurul- (1/56), kuş $(1 / 46,5,67,6 / 37,7 / 67)$, Kuş(7/67), Kuzey (3/63), kuzgun (6/70), küçük (3/64, 3/65, 3/66, 6/71, 6/72, 6/73, 6/91, 7/51), kül (6/74), mor (7/59), mutluluk (2/2), ne $(3 / 31,3 / 74,5 / 60)$, nerdesin $(1 / 34,2 / 69)$, o $(2 / 72)$, ocak $(6 / 14)$, oğlan $(2 / 90,7 / 86)$, ol- $(3 / 16,5 / 62)$, olma- $(4 / 34,5 / 69)$, onlar $(7 / 72)$, oyun $(1 / 10)$, öğretmen (2/73), önce (5/65), öte (7/19), öykü (3/95), öyle (3/76), özle- (6/22), paramparça (6/80), parmaklık (1/61), pay $(6 / 65)$, pis $(5 / 66)$, pusu $(3 / 62,5 / 53,6 / 69)$, sarmaşı $(2 / 89)$, savaş (3/35), savaşçı $(2 / 78)$, say $(2 / 21)$, say1lma- $(2 / 21)$, seksenler (7/65), sen $(1 / 63,1 / 64,1 / 77,2 / 37,2,45,2 / 79,2 / 77,7 / 5,3 / 90,6 / 2,6 / 83,7 / 66)$, sensiz $(2 / 80,4 / 34,5 / 69)$, serçe (6/82), sessiz (1/66), sev- (2/4, 2/44, 2/8, 2/13, 3/17, $4 / 35,4 / 37,6 / 23,6 / 83,7 / 14)$, sevgili $(1 / 39,2 / 33,6 / 48,6 / 84)$, sevme- $(7 / 36)$, s1cak (1/67), sir $(3 / 66,6 / 28,6 / 50,6 / 73)$, siradaki (2/6), sil- (4/38), sinekli (1/69), son $(7 / 69,7 / 70)$, sonra $(3 / 96)$, sonsuz $(4 / 39)$, soy $(3 / 4)$, su $(2 / 32,6 / 88)$, suç $(3 / 31$, $3 / 48)$, sudan (7/71), suskun (5/72), sürgün $(1 / 12,7 / 20)$, şen (2/82), şimdi ( $7 / 72)$, taş (2/24), Tatar (1/74), tatl1 (3/83,6/21, 6/91), tatl (6/49), tek (7/75), tekne (4/16), tepe (3/99), tokat (7/60), tutam (4/9), tutsak (3/84), Türk (5/73), ulan (3/86), umut (2/6, $2 / 14,2 / 35,2 / 84,3 / 20,6 / 20)$, umutsuz $(2 / 85,3 / 87)$, unutulma- $(1 / 75)$, uyu- $(3 / 8)$, uzun (7/27), üst (3/52), üzülme- (5/18), var (2/14, 6/20, 7/26), ver- (3/92), vurgun (2/86), yabanc1 $(1 / 43,4 / 23,4 / 40)$, yaka (1/13), yalan $(1 / 24,2 / 8,3 / 60,3 / 94,4 / 10$, $5 / 19,6 / 21)$, yalanc1 $(1 / 77,3 / 45,6 / 91), 6 / 94)$, yalaza (7/76), yamak (7/77), yangin (2/51), yapma- (7/78), yara $(7 / 42,7 / 56)$, yasak $(2 / 87)$, yastık $(7 / 15)$, yaş $(2 / 24)$, yaşa- (3/47), yaşayama- (2/80), Yaz (3/95), yazı (3/55), yazmalı (1/7), yedi (7/79), yedili $(5 / 66)$, yenge $(3 / 21)$, yeni $(5 / 75)$, yeniden $(2 / 9,7 / 81)$, yer $(2 / 45,2 / 51,4 / 22$, $5 / 57,7 / 82)$, yeşil (7/83), yet- $(3 / 20,4 / 37,5 / 41)$, yetme- (6/25), y1l (3/96), y1ldız (6/95), yoksul (1/79), yokuş (7/80), yol (1/14, 3/61, 3/97, 4/43, 5/30, 6/96, 7/84), 
yolculuk (7/85), yuva (2/82, 5/77), yüksek (6/97, 7/82), yürek $(1 / 29,2 / 28,4 / 13$, 5/22, 7/75), yüz (5/78), yüzleş- (3/98).

\subsection{Türkçe ve Türkçe Söz Varlığı}

Aşağıda madde başı olan Türkçe ve Türkçe kelimeler, tüm dizi adlarında kullanıldığ yerlerin kodları ile birlikte listelenmiştir.

Abur cubur (7/2), ad koy- (4/2, 5/3, 6/2, 7/5), akşam ol- (5/42), alın yazıs1 (3/3), Altın Dağlı (5/8), analı oğullu (3/5, 5/9), ay tutul- (6/13), Bayram Bayram (7/4), biçak sırtı (4/7), boynu bükük (3/23), bugün (1/23), Çalıkuşu (3/26), deniz kızı (6/33), deniz yıldızı (2/31, 5/26), dolunay (6/35), delikanlı (5/51), Ertuğrul (7/25), gece gündüz (3/32), Gece Sesleri (5/38), gökkuşağ 1 (7/31), gönülçel(1/37), gözyaşı (3/19), Karadağlar (5/49), Karadayı (1/47), Karadeniz (1/63), karakol (5/50), Karayel (3/77), Karayılan (1/48), kız kaçır- (1/52), koca koca (3/60), kuşdili (1/57), Kuzey Yıldızı (5/52), küstüm çiçeği (7/52), n'ol- (2/68), oyunboz(5/64), sarı sarı (4/33), ufak tefek (6/92), yer gök $(2 / 88,4 / 42)$, yersiz yurtsuz (1/78), yıldırım düş- (5/32), Yılanların Öcü (5/76), yüzyıl (2/67, 5/59, 6/77, 7/27).

\subsection{Türkçe, Türkçe ve Arapça Söz Varlığı}

Aşağıda madde başı olan birleşik kelimelerin ve özel ad ifade etmek üzere bir araya getirilen kelimelerin bütünlüğü bozulmadan köken tespitleri yapılmıştır.

Hanımeli Sokağı (7/37), Yedi Güzel Adam (7/79).

\subsection{Türkçe ve Arapça Söz Varlığı}

Aşağıda özel ad ifade etmek üzere bir araya getirilen kelimelerin bütünlüğü bozulmadan köken tespitleri yapılmıştır.

Yedikule (7/80).

\subsection{Türkçe ve Farsça Söz Varlığı}

Aşağıda madde başı olan birleşik kelimelerin ve özel ad ifade etmek üzere bir araya getirilen kelimelerin bütünlüğü bozulmadan köken tespitleri yapılmıştır.

Deli divane (4/12), Es Es-Eskişehir (5/31), güzel çirkin (3/38), karagül (2/53), sonbahar (6/89), Türkan (3/85).

\subsection{Türkçe ve Fransizca Söz Varlığı}

Aşağıda madde başı olan birleşik kelimelerin bütünlüğü bozulmadan köken tespitleri yapılmıştır.

Başrol (7/13). 


\subsection{Türkçe ve Rumca Söz Varlığı}

Aşağıda madde başı olan birleşik kelimelerin bütünlüğü bozulmadan köken tespitleri yapılmıştır.

Hanımefendi (7/51).

\subsection{Arapça ve Türkçe Söz Varlığı}

Aşağıda madde başı olan birleşik kelimelerin ve özel ad ifade etmek üzere bir araya getirilen kelimelerin bütünlüğü bozulmadan köken tespitleri yapılmıştır.

Affedilme- (1/2), affet- (1/3, 5/17, 6/18), aşık ol- (7/43), hükümdar ol- (1/33), kaderi yaz1l- (6/60), kalbi at- (5/47), kalbine yaz- (5/5), kaybet- (7/45), kayıp aran- (7/46), kayıtdışı (2/55), mucize ol- (2/19), sınıfta kal- (2/12), sır ver- (2/77), talih kuşu (1/73), Yunus Emre (7/85).

\subsection{Arapça, Türkçe ve Türkçe Söz Varlığı}

Aşağıda madde başı olan birleşik kelimelerin ve özel ad ifade etmek üzere bir araya getirilen kelimelerin bütünlüğü bozulmadan köken tespitleri yapılmıştır.

Aklı başına gel- (4/4), Sevda Kuşun Kanadında (7/67), Şevkat Yerimdar $(2 / 83)$.

\subsection{Arapça, Türkçe ve Farsça Söz Varlığı}

Aşağıda özel ad ifade etmek üzere bir araya getirilen kelimelerin bütünlüğü bozulmadan köken tespitleri yapılmıştır.

Ferhat ile Şirin (2/40).

\subsection{Arapça, Türkçe, Farsça ve Arapça Söz Varlığı}

Aşağıda özel ad ifade etmek üzere bir araya getirilen kelimelerin bütünlüğü bozulmadan köken tespitleri yapılmıştır.

Ferhat ile Şirin Hikâyesi (2/18).

\subsection{Farsça ve Türkçe Söz Varlığı}

Aşağıda madde başı olan birleşik kelimelerin ve özel ad ifade etmek üzere bir araya getirilen kelimelerin bütünlüğü bozulmadan köken tespitleri yapılmıştır.

Ateşe yürü- (6/10), canevim (1/25), canını sev- (7/22), çoban yıldızı (2/26), ferman dinleme- (5/39), Gültepe (3/14), kelepçe vurulma- (2/84), kördügüum (2/61, 4/29), Şahin Tepesi (1/71), vazgeçme- (5/11). 

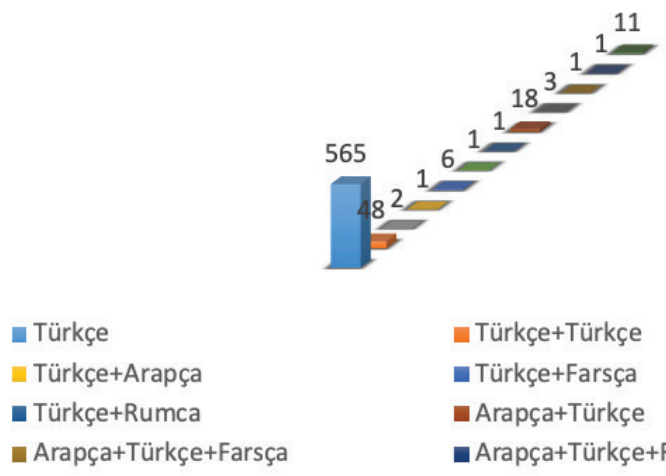

n Türkçe+Türkçe

- Türkçe+Farsça

- Arapça+Türkçe

- Arapça+Türkçe+Farsça+Arapça

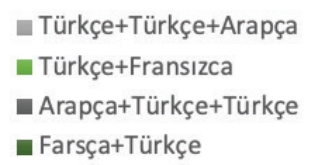

Grafik 1. Dizi Adlarında Türkçe, Türkçe ve Diğer Diller, Diğer Diller ve Türkçe Kelimelerin Oransal Dağılımı

Grafik 1'de içerisinde Türkçe kökenli kelimelerin yer aldığ 1 Türkçe, Türkçe ve Türkçe, Türkçe ve alıntı, alıntı ve Türkçe söz varlığı kategorilerindeki kelimelerin istatistiksel olarak durumları tespit edilmiştir. Buna göre dizi adlarında 565 adet olmak üzere en çok Türkçe kelimeler tercih edilmiştir. 48 adet kelimenin yer ald1ğ1 Türkçe ve Türkçe kategorisi ikinci sırada yer alırken Arapça, Türkçe ve Farsça ile Arapça, Türkçe, Farsça ve Arapça kategorilerinde sadece birer adet özel ad niteliğindeki birleşik yapılı kelimeler tespit edilmiştir. Aynı zamanda dizi adları oluşturulurken kullanılan kelimelerin kökeni dikkate alındığında Türkçe kelimelerden sonra en çok Türkçe kelimelerle Arapça ve Farsça kökenli kelimelerin birleştirilmesiyle oluşturulan kelimeler tercih edilmiştir. Türkçe ve Arapça, Farsça kelimelerin birleştirilmesiyle oluşturulan kelimeler dışında bir adet Türkçe ve Rumca, bir adet de Türkçe ve Fransızca şeklinde oluşturulan iki adet kelime tespit edilmiştir.

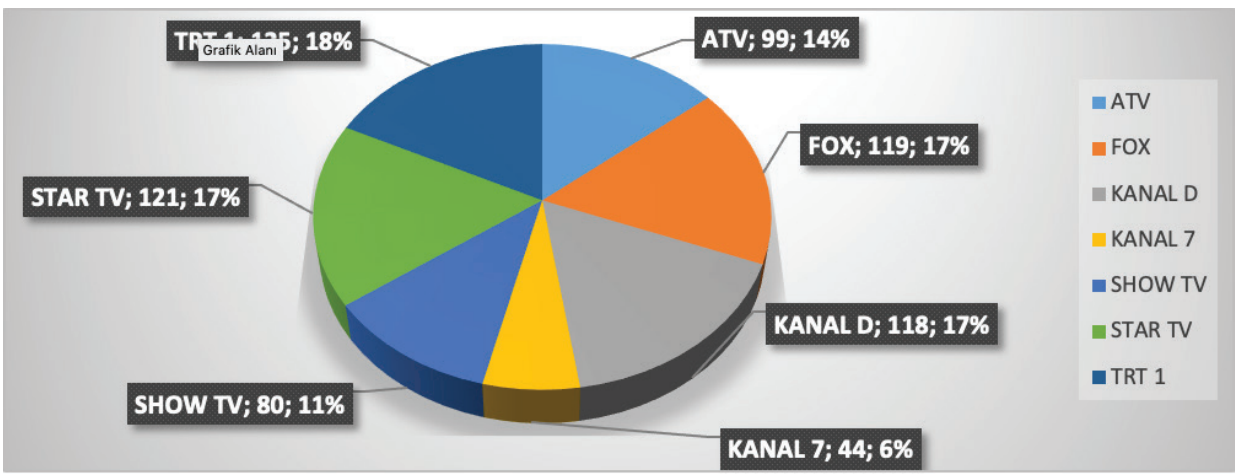

Grafik 2. Dizi Adlarındaki Türkçe Kelimelerin Kanallardaki Dağılımı 
Grafik incelendiğinde Türkçe kelimelerin en fazla TRT 1'de kullanıldığ1 görülmektedir. Türkçe kelimelerin en az kullanıldığı kanal ise Kanal 7'dir.

Tablo 2. Dizi Adlarında En Sık Kullanılan Türkçe Kelimeler

\begin{tabular}{|c|c|c|c|c|c|}
\hline Kelime & Siklık & Kelime & Sıklık & Kelime & Sıklık \\
\hline Bir & 23 & Str & 4 & Durak & 2 \\
\hline Ben & 21 & Yalancl & 4 & Durum & 2 \\
\hline$B a b a$ & 10 & Yüzyıl & 4 & Duymak & 2 \\
\hline Çocuk & 9 & Arkadaş & 3 & Ekmek & 2 \\
\hline$K l z$ & 9 & Demek & 3 & Elma & 2 \\
\hline Sen & 9 & Gelin & 3 & İlişki & 2 \\
\hline Küçük & 8 & Kelebek & 3 & $\dot{I n c i}$ & 2 \\
\hline Sevmek & 8 & Ile & 3 & $\dot{I}_{S ̧}$ & 2 \\
\hline Anne & 7 & $\dot{I}_{\text {çin }}$ & 3 & Kalmak & 2 \\
\hline Yol & 7 & Olmak & 3 & Kanit & 2 \\
\hline$B i z$ & 7 & Pusu & 3 & Koku & 2 \\
\hline$A d$ & 6 & Var & 3 & Düğüm & 2 \\
\hline$E v$ & 6 & Tatll & 3 & Oğlan & 2 \\
\hline Güzel & 6 & $\dot{I} k i$ & 3 & Olmamak & 2 \\
\hline Yalan & 6 & $\mathrm{Ne}$ & 3 & $\mathrm{Su}$ & 2 \\
\hline Deli & 6 & Sensiz & 3 & Suç & 2 \\
\hline Umut & 6 & Büyük & 3 & Sürgün & 2 \\
\hline Kurt & 5 & Kara & 3 & Yabancl & 2 \\
\hline Yer & 5 & Yetmek & 3 & Yara & 2 \\
\hline Yürek & 5 & Ăgaç & 2 & Yer Gök & 2 \\
\hline Hanım & 5 & Anlatmak & 2 & Umutsuz & 2 \\
\hline Ad koymak & 4 & Analı Oğullu & 2 & Nerdesin & 2 \\
\hline$A h$ & 4 & Bebek & 2 & Böyle & 2 \\
\hline Gönül & 4 & Bulut & 2 & Yeniden & 2 \\
\hline Gün & 4 & Çiçek & 2 & $\mathrm{Acl}$ & 2 \\
\hline Kardeş & 4 & $D e$ & 2 & Geniş & 2 \\
\hline Kuş & 4 & Deniz & 2 & $\dot{I l l k}$ & 2 \\
\hline Sevgili & 4 & Denizylldızı & 2 & Son & 2 \\
\hline
\end{tabular}

Yukarıdaki tabloda dizi adlarındaki Türkçe kökenli kelimeler ile bu kelimelerin kullanım sıklıkları listelenmiştir. Buna göre birden fazla tekrar eden madde başı Türkçe kelime sayısı 84 'tür. Bilindiği üzere söz varlığı tespit çalışmalarında özellikle son yıllarda teknolojik gelişmelerin de konuyla ilgili sunduğu imkânlara bağlı olarak kelime sıklığı araştırmaları giderek önem kazanan bir çalışma sahası 
olmuştur. Bu türden çalışmaların dünya literatüründeki tarihi daha eski olmakla birlikte ülkemizde de 1980 'lerden itibaren hız kazanmış durumdadır. Sıklık çalışmaları, belirtildiği üzere söz varlığını oluşturan kelimelerin durumunu tespit etmek açısından önem arz etmekle birlikte ana dili ya da yabancı dil öğretimi bakımından da öncelikli öğrenilmesi gereken kelimeleri belirleyerek zaman kazanılmasına ve daha etkin bir öğrenme koşulu sağlanmasına katkı sunmaktadır. Sıklık çalışmaları sadece dil birimlerinin durumunu değil, aynı zamanda toplumun eğitim, psikoloji, sosyoloji gibi alanlarda hatta iletişim kurduğu toplumlarla olan münasebetinin de betimlenmesi noktasında önemli bir çalışma sahası olarak görülmektedir.

\section{2. İçerisinde Türkçe Kökenli Kelimelerin Yer Almadığı Söz Varlığı}

Bu kategoride, dizi adlarında yer alan madde başı her bir kelime Arapça ve diğer diller, Farsça ve diğer diller, diğer diller ve diğer diller şeklinde oluşturulan başlıklar altında tasniflenmiştir.

\subsection{Arapça Söz Varlığı}

Aşağıda madde başı olan Arapça kelimeler, tüm dizi adlarında kullanıldığı yerlerin kodları ile birlikte listelenmiştir.

Acayip (6/1), acemi (7/3), acil (5/2,5/4), adam (7/79), Ahmet (7/77), aile $(1 / 5,1 / 26,2 / 15,2 / 59,3 / 12,3 / 33,4 / 11,6 / 3,6 / 42)$, Ali $(2 / 4)$, Aliye $(1 / 6,4 / 5)$, aman (1/8), araf (2/5), asla (5/11), aşk (1/10, 1/11, 1/34, 1/12, 2/1, 2/8, 2/9, 2/10, 2/16, 2/46, 2/47 2/88, 3/10, 3/11, 3/17, 3/40, 3/79, 3/92, 4/8, 4/9, 4/42, 5/1, 5/2, $5 / 12,5 / 13,5 / 14,5 / 52,6 / 7,6 / 8,6 / 66,6 / 71,7 / 8,7 / 13,7 / 33,7 / 85)$, Ayşe (2/4), azap (1/14), bakkal (1/69), bazen (6/49), bedel (2/74, 4/32, 6/7), belal1 (1/17), beyaz $(1 / 19,2 / 58,5 / 19)$, cennet $(1 / 27,6 / 28)$, cesur $(5 / 22,6 / 29)$, Cevdet $(7 / 40)$, cinayet $(3 / 24,6 / 92)$, Cuma $(3 / 25)$, defter $(2 / 71)$, devir $(2 / 63,5 / 54)$, devriye $(7 / 54)$, dolap (2/29), dükkan (5/55), dünya (1/33, 3/94), Düriye (6/36), Elif (4/15), emanet (2/36), Emir (5/30), esaret (2/37), esir (7/28), eşkiya (1/33), evlat $(3 / 29,6 / 16)$, evvel (7/30), Ezel (1/35, 5/33), ezelden (3/88, 6/93), Ezra (5/34), fakir (2/90, 7/86), Fatih (3/30), fatih (3/69), Fazilet (6/39), feda (4/17), Feriha (4/2, 5/3), Firat (7/62), firar (6/40), gamsiz (5/37), garip (4/8), Gazi (1/36), gurbet (7/33), gurur $(3 / 10,5 / 14)$, hal $(1 / 22,2 / 10)$, hala $(2 / 14,6 / 20)$, halka $(7 / 35)$, harem $(2 / 43)$, hatıra $(4 / 24)$, hatırla- $(1 / 39,6 / 48)$, Hayal $(1 / 40)$, hayal $(5 / 13)$, hayat $(2 / 44,2 / 65$, 2/72, 3/40, 3/41, 3/43, 4/1, 4/18, 4/26, 5/37, 6/49, 6/50, 7/26, 7/38, 7/39, 7/80), Hayati (3/42), hazreti $(4 / 194 / 20,4 / 21)$, hesap (6/71), hesaplaş- (7/41), Hicran (3/13), hicran (7/42), hikâye $(2 / 15,2 / 16,2 / 18,2 / 20,3 / 17,6 / 1,7 / 29,7 / 30)$, iffet (6/53), İffet (6/53), ihanet $(6 / 54)$, inat $(2 / 47,3 / 47)$, intikam $(3 / 49,3 / 83)$, isimsiz (3/50), isyan (7/7), işgal (4/25), kadim (2/49), kalbimdeki (2/52), kalp (2/51, 
2/76, 3/53, 4/3, 4/7, 5/28, 6/61, 6/62, 7/6, 7/56), kanun (7/8, 7/50), kayıp (3/56, $3 / 57,4 / 26)$, Kemal (2/73, 5/74), kere (6/83), kırmız1 (6/67), Leyla (7/53), mahalle $(1 / 59,3 / 28)$, mahşer $(1 / 60)$, makber (6/75), mal (5/73), masal $(1 / 21,3 / 22$, 4/36, 7/16), masum (3/68), Mavi (1/11), mavi (7/55), mazi (7/56), Mecnun (7/53), melek (2/64, 2/81, 5/58, 6/19), Mehmed (3/69), mehmetçik (7/57), Memo (3/46), merhaba (2/65), merhamet (3/70), Meryem (3/71, 4/19), mesele (3/81), mevsim $(2 / 57,6 / 61)$, mihrap (5/57), milat (7/58), mucize $(2 / 66,3 / 41)$, muhtar (1/59), muhteşem $(2 / 67,3 / 72,5 / 59,6 / 77)$, müezzin (7/3), mükemmel (3/73), münasebet (5/60), nöbet (5/61), Nuri (3/75), Osman (1/56), Osmanlı $(7 / 17,7 / 60)$, Ömer (4/20), ömür $(2 / 74,4 / 32,6 / 25)$, Ramazan $(1 / 74)$, reis $(6 / 3)$, ruh $(2 / 75)$, saadet $(1 / 5,2 / 25)$, saat $(1 / 67,7 / 40,7 / 64)$, Salih $(5 / 67)$, sebep $(7 / 71)$, sefir $(6 / 81)$, servet $(1 / 65,5 / 68)$, sevda $(3 / 78,4 / 36,5 / 20,6 / 63,7 / 67)$, sevdaluk $(5 / 70)$, Seyit (6/68), Sila (1/68), sinif $(5 / 71,7 / 68)$, sirat $(6 / 85)$, sihirli $(6 / 86)$, sofra $(7 / 34)$, sokak (5/46), Sultan (3/80, 6/62, 7/28), şahit (6/95), şehir (2/81, 3/57), şeref (3/81), şöhret (1/72), şubat (7/73), Şura (6/68), şüphe (3/82), tacir (7/74), takip (4/28), teşekkür $(5 / 62)$, vadi $(3 / 62,4 / 30,5 / 53,6 / 69)$, vatan $(3 / 90,5 / 65)$, ve $(1 / 11,1 / 40$, $1 / 79,2 / 55,3 / 10,3 / 11,3 / 42,5 / 14,6 / 6,6 / 16,6 / 29,6 / 39,6 / 68,6 / 74)$, veda $(3 / 91)$, vicdan (3/93), yemin $(4 / 41)$, zaman $(2 / 5,3 / 76,6 / 43,7 / 17,7 / 30)$, Zehra $(2 / 3)$, zemheri (5/79), zeytin (3/99).

\subsection{Arapça ve Arapça Söz Varlığı}

Aşağıda madde başı olan birleşik kelimelerin ve özel ad ifade etmek üzere bir araya getirilen kelimelerin bütünlüğü bozulmadan köken tespitleri yapılmıştır.

Aşk-1 Memnu (3/9), Aşkın Kanunu (7/8), Fatih Harbiye (2/39), ibreti alem (6/51), medcezir (6/76), Nefes Nefese (6/78), Seddülbahir (7/64).

\subsection{Arapça ve Farsça Söz Varlığı}

Aşağıda özel ad ifade etmek üzere bir araya getirilen kelimelerin bütünlüğü bozulmadan köken tespitleri yapılmıştır.

Fatmagül (3/31), Hindistan (2/46).

\subsection{Arapça ve Fransızca Söz Varlığı}

Aşağıda özel ad ifade etmek üzere bir araya getirilen kelimelerin bütünlüğü bozulmadan köken tespitleri yapılmıştır.

Kahireli $^{32}$ Palas (2/50). 


\subsection{Arapça ve İbranice Söz Varlığı}

Aşağıda özel ad ifade etmek üzere bir araya getirilen kelimelerin bütünlüğü bozulmadan köken tespitleri yapılmıştır.

Halil İbrahim (7/34).

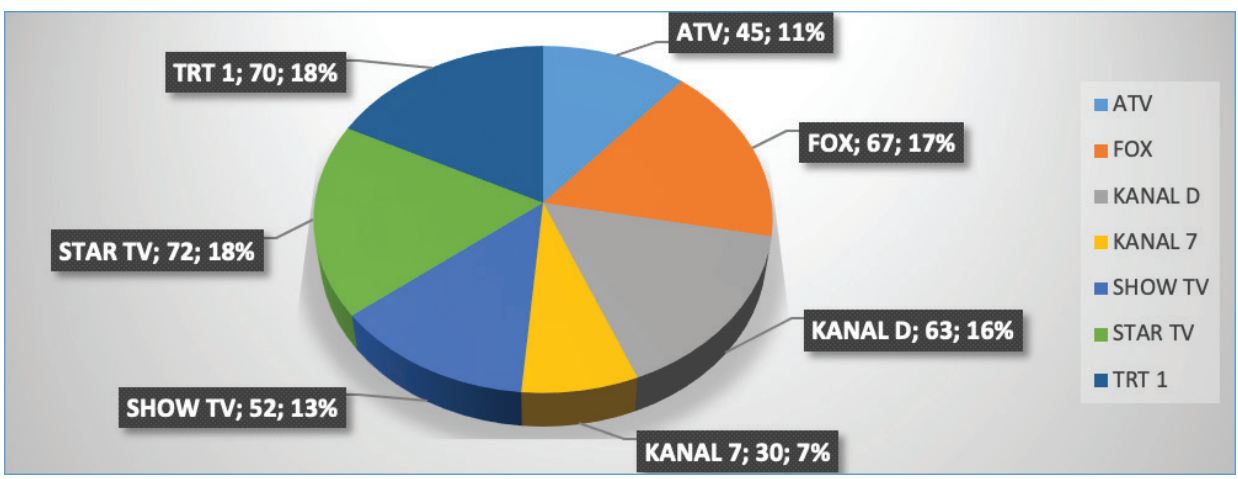

Grafik 3. Dizi Adlarındaki Arapça Kelimelerin Kanallardaki Dağılımı

Grafik incelendiğinde Arapça kökenli kelimelerin en fazla Star TV'de kullanıldığ̣ görülmektedir. Arapça kökenli kelimelerin en az kullanıldığı kanal ise Kanal 7'dir.

Tablo 3. Dizi Adlarında En Sık Kullanılan Arapça Kelimeler

\begin{tabular}{lclclc}
\hline Kelime & Sıklık & Kelime & Siklık & Kelime & Sıklık \\
\hline Aşk & 36 & Ömür & 3 & Hayal & 2 \\
Hayat & 14 & Saat & 3 & Intikam & 2 \\
Ve & 15 & Hazreti & 3 & Kanun & 2 \\
Kalp & 11 & Acil & 2 & Kayıp & 2 \\
Aile & 9 & Beyaz & 2 & Mucize & 2 \\
Hikaye & 8 & Fakir & 2 & Saadet & 2 \\
Sevda & 5 & Cennet & 2 & Servet & 2 \\
Masal & 4 & Cinayet & 2 & SinlfŞarkı & 2 \\
Melek & 4 & Devir & 2 & Şehir & 2 \\
Vadi & 4 & Durak & 2 & Vatan & 2 \\
Zaman & 4 & Durum & 2 & Ezelden & 2 \\
Muhteşem & 4 & Evlat & 2 & Hala & 2 \\
Af & 3 & Hal & 2 & Inat & 2 \\
Bedel & 3 & Hatırlamak & 2 & Osmanl & 2 \\
\hline
\end{tabular}


Yukarıdaki tabloda dizi adlarındaki Arapça kökenli kelimeler ile bu kelimelerin kullanım sıklıkları listelenmiştir. Buna göre birden fazla tekrar eden madde başı Arapça kökenli kelime sayısı 43’tür.

\subsection{Farsça Söz Varlığı}

Aşağıda madde başı olan Farsça kelimeler, tüm dizi adlarında kullanıldığ 1 yerlerin kodları ile birlikte listelenmiştir.

Asayiş (2/7), ateş $(3 / 52,6 / 9,6 / 74)$, ayna $(2 / 75,7 / 10)$, bahar $(1 / 44,6 / 94)$, bahçe (3/78), Behzat Ç. (6/17), birader (2/69), cam (7/21), can $(1 / 26,2 / 23,4 / 11,5 / 21$, 6/27,7/12), Can (3/46), Canan (2/22), cihan (3/69), çember (6/30), çift (3/73), çiftlik (3/39), çifte $(2 / 25)$, damat $(4 / 40,6 / 90)$, destan (7/70), diğerleri (3/42), Dila (5/27, 6/34), dost (2/49,3/28), duvar (1/31), düşman (5/29, 5/77, 7/10), Efsane (3/1), Firuze (5/36), gül (3/35), günah (3/11,6/15), günahkâr (2/42), her (2/45), hoca (1/3), kahraman (5/48), ki (3/76), köy (7/44), köylü $(6 / 46,6 / 47)$, lale $(2 / 63,5 / 54)$, leke (3/67), menekşe (7/59), Neriman (5/7), Nevzat (1/54), rüzgâr $(2 / 17,2 / 76)$, saray $(6 / 82,7 / 63)$, saraylı $(1 / 23,5 / 25)$, siyah (6/87), şahane (6/90), şark1 $(3 / 43,7 / 61)$, Ustura (5/74), zehirli (2/89), zengin (1/79, 2/90, 7/86), Zerda (1/80, 4/44).

\subsection{Farsça ve Farsça Söz Varlığı}

Aşağıda madde başı olan birleşik kelimelerin ve özel ad ifade etmek üzere bir araya getirilen kelimelerin bütünlüğü bozulmadan köken tespitleri yapılmıştır.

Gülperi (5/40), yaban gülü (1/76).

\subsection{Farsça ve Arapça Söz Varlığı}

Aşağıda madde başı olan birleşik kelimelerin ve özel ad ifade etmek üzere bir araya getirilen kelimelerin bütünlüğü bozulmadan köken tespitleri yapılmıştır.

Berkemal (2/7), Gülizar (3/34), hercai (1/42), siyah beyaz (3/79).

\subsection{Farsça ve Yunanca Söz Varlığı}

Aşağıda madde başı olan birleşik kelimelerin bütünlüğü bozulmadan köken tespitleri yapılmıştır.

Zoraki (7/87).

\subsection{Farsça, Arapça ve Farsça Söz Varlığı}

Aşağıda özel ad ifade etmek üzere bir araya getirilen kelimelerin bütünlüğü bozulmadan köken tespitleri yapılmıştır.

Keşanlı Ali Destanı (3/58). 


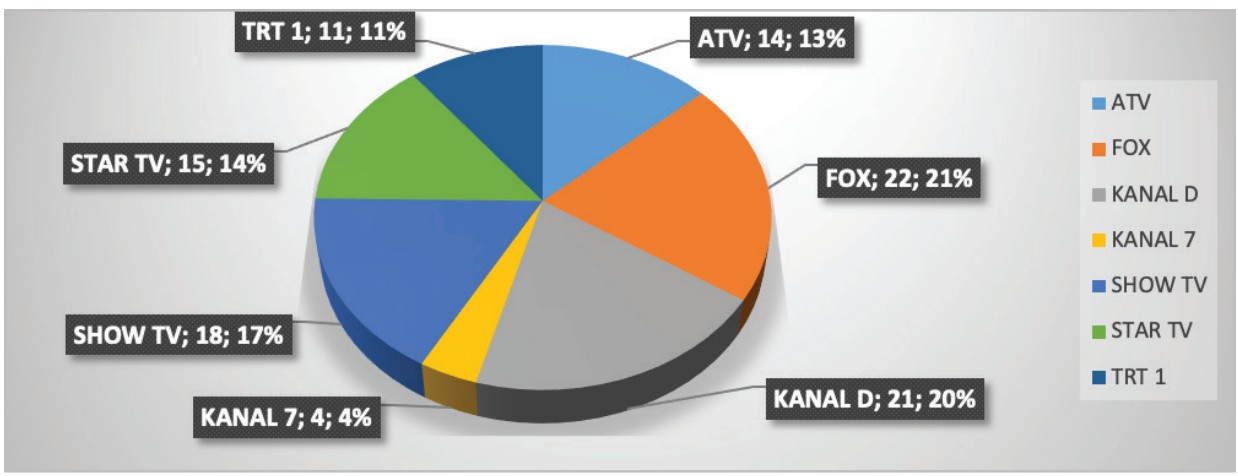

Grafik 4. Dizi Adlarındaki Farsça Kelimelerin Kanallardaki Dağılımı

Grafik incelendiğinde Farsçadan alıntı kelimelerin en fazla Fox’ta kullanıldığ görülmektedir. Farsça kökenli kelimelerin en az kullanıldığı kanal ise Kanal 7'dir.

Tablo 4. Dizi Adlarında En Sık Kullanılan Farsça Kelimeler

\begin{tabular}{lclc}
\hline Kelime & Sıklık & Kelime & Sıklık \\
\hline Can & 6 & Gül & 2 \\
Saray & 4 & Günah & 2 \\
Ateş & 3 & Kör & 2 \\
Bahar & 2 & Köylü & 2 \\
Damat & 2 & Lale & 2 \\
Dost & 2 & Rüzgar & 2 \\
Düşman & 2 & Zengin & 2 \\
\hline
\end{tabular}

Yukarıdaki tabloda dizi adlarındaki Farsça kökenli kelimeler ile bu kelimelerin kullanım sıklıkları listelenmiştir. Buna göre birden fazla tekrar eden madde başı Farsça kökenli kelime sayısı 14'tür.

\subsection{Fransızca Söz Varlı̆ğı}

Aşağıda madde başı olan Fransızca kelimeler, tüm dizi adlarında kullanıldığı yerlerin kodları ile birlikte listelenmiştir.

Akasya (3/2, 6/4), dans (5/6), doktor (2/34, 2/66, 4/14), kanal (7/23), klavye $(5 / 51)$, kobra $(4 / 28)$, komiser $(1 / 54,7 / 48)$, kontrbas $(2 / 54)$, lise $(7 / 54)$, manyak (5/55), müzik (4/31), not (2/71), prens $(7 / 61)$, servis $(5 / 4)$, sosyete $(6 / 58,6 / 97)$, süper (1/70), taksi (1/28). 


\subsection{Fransızca ve Farsça Söz Varlığı}

Aşağıda özel ad ifade etmek üzere bir araya getirilen kelimelerin bütünlüğg̈ bozulmadan köken tespitleri yapılmıştır.

Otel Divane (5/63).

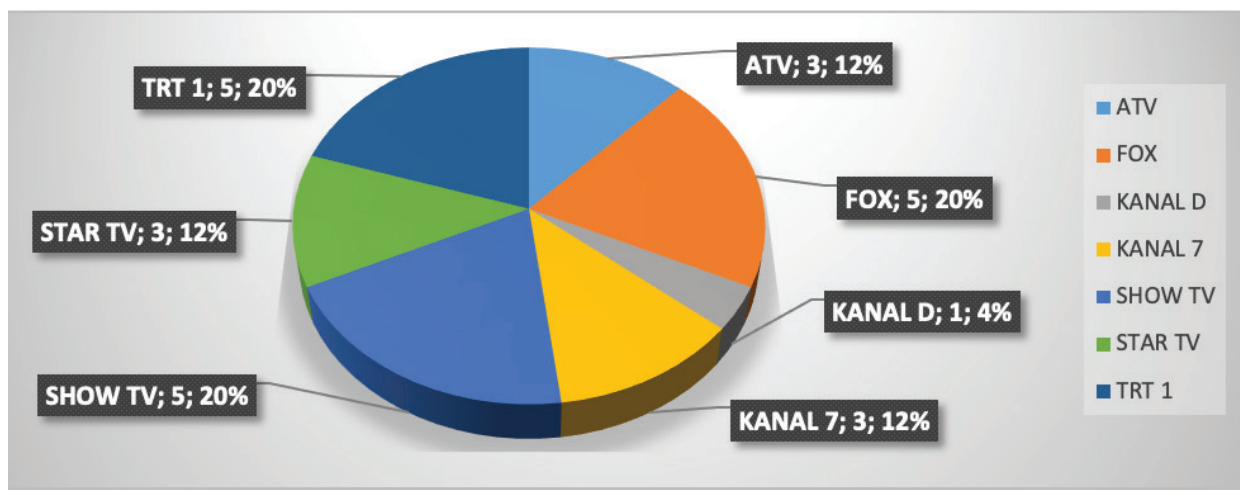

Grafik 5. Dizi Adlarındaki Fransızca

Kelimelerin Kanallardaki Dağılımı

Grafik incelendiğinde Fransızca kökenli kelimelerin en fazla TRT 1, FOX ve Show TV'de kullanıldığı görülmektedir. Fransızca kökenli kelimelerin en az kullanıldığı kanal ise Kanal D'dir.

\subsection{3. İngilizce Söz Varlığı}

Dizi adlarından yalnızca bir adet İngilizce kelime tespit edilmiştir. Jet $(6 / 58)$.

\subsection{Rumca Söz Varlığı}

Dizi adlarından tespit edilen 11 adet Rumca kelime aşağıdaki gibidir.

Avlu (6/11), Bodrum (3/22), demet (1/20), efendi (4/31), güğüm (6/36), kiraz (2/57), kutu (3/54), limon (1/58), mayıs (5/56), papatya (6/79), Poyraz $(3 / 77)$.

\subsection{5. İtalyanca Söz Varlığı}

Dizi adlarından 9 adet İtalyanca kelime tespit edilmiştir.

Avrupa (1/13), Avrupa Avrupa (7/9), fabrika (5/35), familya (2/38), firtına $(2 / 56,6 / 52)$, lira $(4 / 33)$, no $(2 / 70)$, tiyatro $(1 / 20)$. 


\subsection{6. Çince Söz Varlı̆̆ı}

Dizi adlarında 1 adet Çince kelime TRT 1'den tespit edilmiştir.

Mant1 (7/1).

\subsection{Sırpça Söz Varlığı}

Dizi adlarında kelime sıklığı 2 olan kraliçe, Show ve Star'dan tespit edilmiştir. Kraliçe (5/56, 6/41).

\subsection{Yunanca Söz Varlığı}

Dizi adlarında 1 adet Yunanca kelime Kanal D'den tespit edilmiştir.

Litre (3/19).

\subsection{9. İbranice Söz Varlı̆ğ}

Dizi adlarında kelime sıklığı 2 olan Yusuf, Kanal 7 ve TRT 1'den tespit edilmiştir.

Yusuf $(4 / 21,7 / 16)$.

\subsection{Hintçe ve Arapça}

Aşağıdaki birleşik yapılı coğrafya adı TRT 1'den tespit edilmiştir.

Kut'ül Amare (7/57).

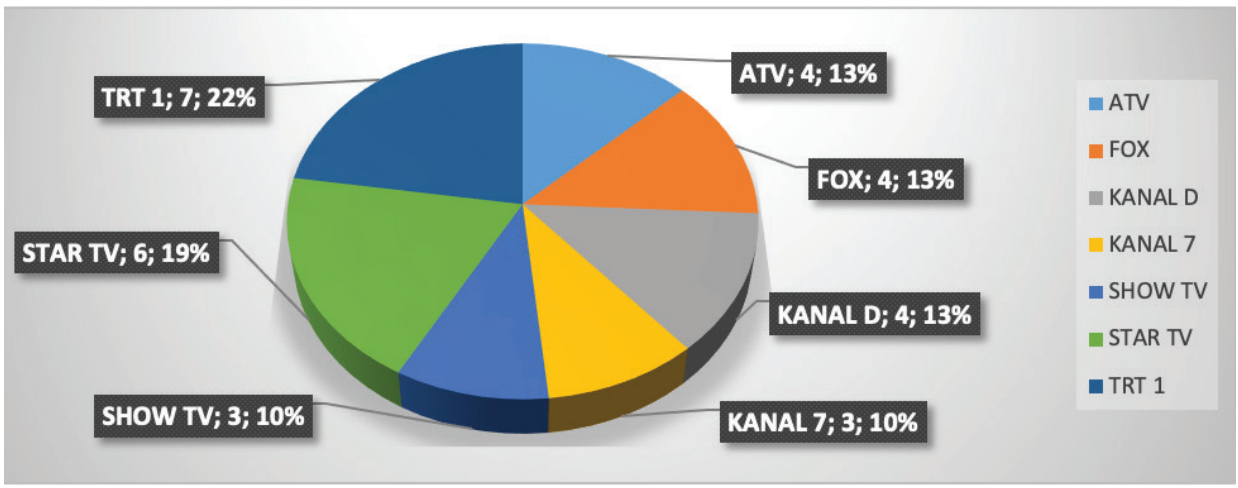

Grafik 6. Dizi Adlarındaki Diğer Dillerden Kelimelerin Kanallardaki Dağılımı

Grafik incelendiğinde Türkçe, Arapça, Farsça ve Fransızca dışındaki diğer dillerin kelimelerinin en fazla TRT 1'de kullanıldığı görülmektedir. Diğer dillerin kelimelerinin en az kullanıldığ 1 kanallar Kanal 7 ve Show TV'dir. 


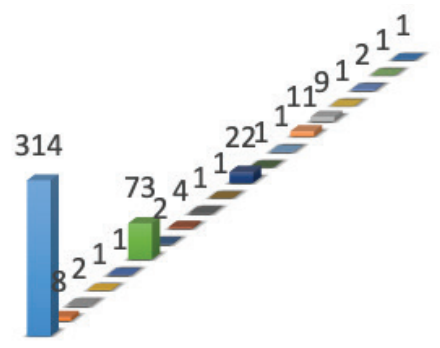

$\begin{array}{lll}\square \text { Arapça } & \square \text { Arapça+Arapça } & \text { Arapça+Farsça } \\ \text { Arapça+Fransızca } & \square \text { Arapça+Ibranice } & \square \text { Farsça } \\ \square \text { Farsça+Farsça } & \square \text { Farsça+Arapça } & \square \text { Farsça+Yunanca } \\ \square \text { Farsça+Arapça+Farsça } & \square \text { Fransızca } & \square \text { Fransızca+Farsça } \\ \text { İngilizce } & \text { Rumca } & \square \text { İtalyanca } \\ \text { Çince } & \square \text { Sırpça } & \text { Yunanca }\end{array}$

Grafik 7. Dizi Adlarındaki Diğer Dillerden Kelimelerin Oransal Dağılımı

Grafik 7'de içerisinde Türkçe kökenli kelimelerin yer almadığ1 söz varlığı unsurları Arapça; Arapça ve diğer diller; diğer diller ve Arapça; Farsça; Farsça ve diğer diller; diğer diller ve Farsça; Fransızca; Fransızca ve diğer diller; diğer diller ve diğer diller şeklinde oluşturulan kategorilerde istatistiksel olarak betimlenmiştir. Buna göre gerek tek başına gerekse başka dillerden alıntı kelimelerle birleştirilerek dizi adlarında en çok kullanılan kelimeler, Arapça kökenlidir. Bu kategoride Farsça kökenli kelimeler ikinci, Fransızca kökenli kelimeler ise üçüncü sırada yer alırken sayıları çok az olmakla birlikte Çince, İbranice, Rumca, Sırpça, Yunanca gibi diğer dillerden alıntı kelimeler de tespit edilmiştir. Dolayısıyla Türkçe kökenli kelimelerin yer almadığı söz varlığında en çok Arapça, ikinci sırada Farsça, üçüncü sırada ise Fransızca kelimeler ve bu kelimelerin türetilmesi ya da bu kelimelerle başka dillerden kelimelerin birleştirilmesiyle oluşturulan yeni kelimeler yer almaktadır.

Tablo 5. Dizi Adlarında En Sık Kullanılan Diğer Kökenli Kelimeler

\begin{tabular}{lc}
\hline Kelime & Sıklık \\
\hline Istanbul & 8 \\
Doktor & 3 \\
Akasya & 2 \\
Firtına & 2 \\
Kraliçe & 2 \\
Sosyete & 2 \\
Urfall & 2 \\
Komiser & 2 \\
\hline
\end{tabular}


Yukarıdaki tabloda dizi adlarındaki diğer kökenli kelimeler ile bu kelimelerin kullanım sıklıkları listelenmiştir. Buna göre birden fazla tekrar eden madde başı diğer kökenli kelime sayısı 8'dir. Bu tabloda en sık kullanılan Ístanbul ve Urfa$l \imath$ kelimelerinin kökenleri belirlenememiştir. Bunun dışında en sık tekrar eden kelimeler olan doktor, akasya, sosyete, ve komiser Fransızcadan alıntı; firtına İtalyancadan alıntı; kraliçe ise Sırpçadan alıntıdır.

\section{Kökeni Belirsiz Söz Varlığı}

Dizi adlarında kökenleri belirlenemeyen kelimeler aşağıda listelenmiştir.

Adanal1 (1/1), Ankara (3/6), Balkan (5/15), Ege (3/53), Heredot (7/40), İstanbul $(1 / 4,1 / 21,3 / 86,4 / 24,5 / 46,6 / 55,7 / 22,7 / 43)$, İstanbullu (6/56), Kafkasya (7/20), Rex (7/48), Sakarya (7/62), Selena (1/62), Urfalı (3/88, 6/93), Üsküdar (3/89).

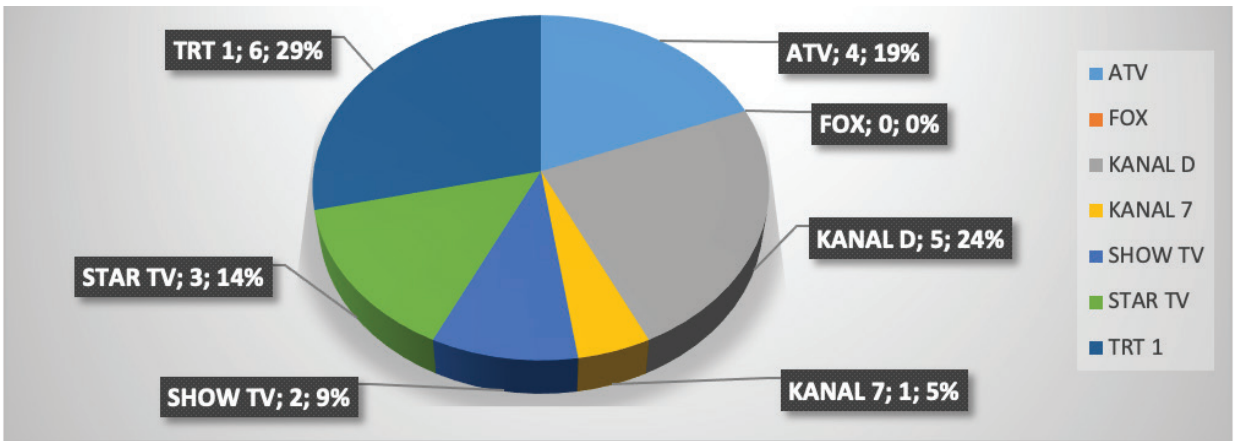

Grafik 8. Dizi Adlarındaki Belirsiz Kökenli Kelimelerin Kanallardaki Dağılımı

Grafik incelendiğinde belirsiz kökenli kelimelerin en fazla TRT 1'de kullanıldığg görülmektedir. Belirsiz kökenli kelimelerin en az kullanıldığ kanal ise Kanal 7'dir. Ayrıca Fox'ta belirsiz kökene ait kelimelerin hiç kullanılmadığı da göze çarpmaktadır.

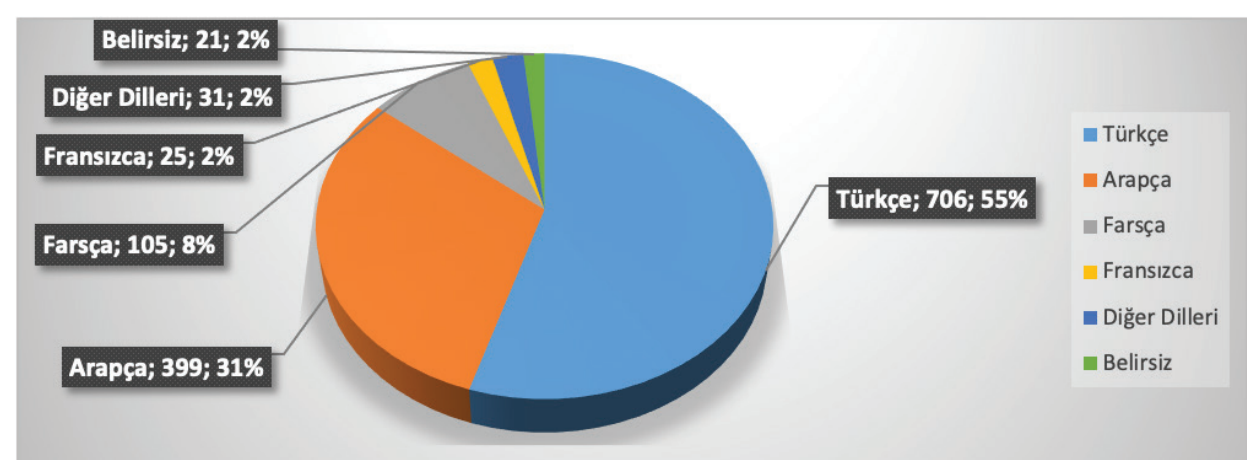

Grafik 9. Dizi Adlarındaki Tüm Kelimelerin Köken Dağılımı 
Grafik incelendiğinde dizi adlarındaki tüm kelimelerin \%55'i yani 706's1 Türkçe kökenli, \%31'i yani 399'u Arapça kökenli, \%8'i yani 105'i Farsça kökenli, \%2'si yani 25'i Fransızca kökenli, \%2,5'i yani 31'i diğer dillere ait ve \%2'si yani 21'i belirsiz kökenli kelimelere aittir.

\section{Sonuç}

Çalışma neticesinde ulaşılan istatistiksel veriler şöyledir: Atv'den 80 dizi adından 169 adet anlamlı ve görevli kelime; Fox'tan 90 dizi adından 217 adet anlamlı ve görevli kelime; Kanal D'den 99 dizi adından 212 adet anlamlı ve görevli kelime; Kanal 7'den 44 dizi adından toplam 85 adet anlamlı ve görevli kelime; Show TV'den 79 dizi adından toplam 160 anlamlı ve görevli kelime; Star TV'den 97 dizi adından toplam 220 adet anlamlı ve görevli kelime; ve TRT 1'den 87 dizi adından toplam 224 anlamlı ve görevli kelime tespit edilmiştir. Dolayısıyla tüm dizilerden toplam 1.287 kelime kökenleri bakımından sınıflandırılmıştır. 1.287 kelimeden 706's1 \%55 oranla Türkçe kökenli, 399'u \%31 oranla Arapça kökenli, 105'i \%8 oranla Farsça kökenli, 25'i \%2 oranla Fransızca kökenli, 31'i \%2 oranla İbranice, Rumca, İngilizce gibi çeşitli dillerden ve 21 'i de $\% 2$ oranla kökeni bilinmeyen kelimelerden oluşmaktadır. İstatistiksel değerlere bakıldığında dizi adlarının yarısının Türkçe kökenli kelimelerle, diğer yarısının ise öncelikli olarak Arapça, Farsça kökenli ve başka dillerden alıntı kelimelerle oluşturulduğu görülmüştür. Dolayısıyla ulaşılan sonuçların Türkçenin tarihî seyirdeki durumu ve en fazla etkileşim yaşadığı dillerin sırasıyla Arapça, Farsça, Fransızca olması durumu ile paralellik gösterdiği ve yine tarafımızca hazırlanmakta olan Ad Bilimi Çerçevesinde TV Dizi Adlarıly İlgili Leksik/Semantik Bir Tasnif Denemesi adlı çalışmada tespit edilen lakap, unvan, kişi adı, yer adı vb. kelime kategorilerinin oluşturduğu parçalar, bütün olarak değerlendirildiğinde dizi adlarında kullanılan Türkçenin kültür tarihiyle de bağının çok kuvvetli olduğunu göstermektedir.

Belirtildiği üzere kitle iletişim araçlarından televizyon, zengininden fakirine, gencinden yaşlısına toplumun her kesimini sosyokültürel anlamda ziyadesiyle etkileyen bir araçtır. Televizyon, dil ve kültürel unsurlar bakımından olumlu gelişmelerin yayılma hızını arttırdığı gibi olumsuz durumların da hızlıca yayılmasına ve yerleşmesine aracılık etmektedir. Yukarıdaki oranlardan yola çıkarak toplum üzerinde etkisi en üst düzeyde olan televizyon ekranlarında her gün yayınlanan dizilerin adlarında Türkçe; yarı Türkçe, yarı İngilizce bir görünüm sergileyen sanal ortamdaki kullanımının aksine Türk dil/kültür tarihiyle bağının hâlen kuvvetli olduğu bir kullanım şekliyle karşımıza çıkmaktadır. Bugün sanal ortamda Türkçe, daha çok dil yanlışları ile örülü (özne-yüklem uyuşmazlığı, aynı anlama gelen kelime kullanımı, kelimelerin yanlış yazılması, noktalama işaretlerinin ye- 
rinde ve doğru kullanılmaması gibi pek çok sorun) bir manzara sergilerken dizi adlarında -ufak tefek yazım yanlışları göz ardı edilirse- daha özenli, ses/şekil

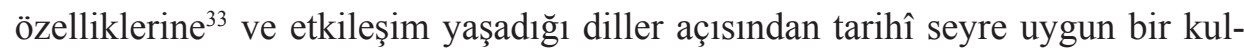
lanım ile dikkat çekmektedir. ${ }^{34}$ Ayrıca dizi adlarında kullanılan Türkçe kökenli kelimeler dışındaki özellikle Arapça, Farsça ve diğer dillerden alıntı kelimelerin giriş kısmında izah edilen kelime alıntılama şekillerinden "dilin ses yahut işletim kurallarına uymuş, yabancılı̆̆ neredeyse belli olmayan kelimeler" maddesine uygun bir kullanım şekli içerdiği söylenebilir. ${ }^{35}$

Dizi adlarında sıklıkla kullanılan ilk on sıradaki Türkçe kelimeler bir, ben, baba, çocuk, klz, sen, küçük, sevmek, anne, yol kelimeleridir. En çok kullanılan bir kelimesi, bugüne kadar Türkçe ile ilgili yapılan sıklık çalışmalarının neticelerinde de ilk beşte yer alan kelimeler arasındadır. ${ }^{36} \mathrm{Baba}$, çocuk, anne, kız gibi kelimeler de aile-akrabalık ilişkilerinin yoğun, bu ilişkileri tanımlayan adların da çeşitlilik gösterdiği Türk toplumunun kültürel yapısına uygunluk göstermektedir. Bunlar dışında sıklıkla kullanılan sır, yalan, ekmek, suç, sürgün, ilişsi, sevgili gibi kelimeler ise dizilerde işlenen konular çerçevesinde yer alan söz varlı̆̆ 1 ögeleridir. Dizi adlarında en sık kullanılan ilk beş sıradaki Arapça kökenli kelimeler; aşk, hayat, kalp ve ailedir. Burada en sık kullanılan aşk kelimesi dizilerde işlenen konularla alakalı iken kalp, hayat, kelimeleri de aynı sebeple dizi adlarında s1k tercih edilen kelimeler arasındadır. Aile ise yukarıda da bahsedilen sebeplerle yani Türk toplumunun kültürel yapısıyla alakalı; ve ise neredeyse tüm sıklık çalışmalarında ilk beş içerisinde yer alan kelimelerdendir. Yine dizi adlarında sık kullanılan can, gül, ateş, günah, dost, düşman gibi Farsça kökenli kelimeler de dizilerde işlenen konularla ilgili söz varlığı ögeleridir. Ayrıca kökeni belirlenemeyen İstanbul da dizilerde işlenen sosyal yaşantıların merkezi konumundaki yer adidir.

33 Y1lmaz - Özkurt, a.g.m.

34 Oğuzhan Durmuş, “Alıntı Kelimeler Bakımından Türkçe Sözlük”, A.Ü. Türkiyat Araştırmalarl Enstitüsü Dergisi, 26, 2004; Osman Yıldız, "Dilimizdeki Arapça ve Farsça Kökenli Kelimelerde Görülen Fonetik Değişmeler”, SDÜ Fen Edebiyat Fakültesi Sosyal Bilimler Dergisi, 4, 1999; Hüseyin Özçakmak - Görkem Yılmaz Tutku, "Yediiklim Türkçe Setinde Arapça Kökenli Sözcüklerin Sıklığı”, Ana Dili Eğitimi Dergisi, 7(4), 2019.

35 Aksan, a.g.e., s. 29.

36 Ahmet Çal, "Türkiye'de Farklı Dönemlere Ait Kelime Sıklığı Çalışmaları Üzerine Bir Değerlendirme", Turkish Studies, 10(8), 2015, s. 715-730. 


\section{Kaynakça}

Akar, Ali, “Türkçe-Arapça Arasındaki Sözcük İlişkileri”, Karadeniz Uluslararası Bilimsel Dergi, 8, 2010.

Akınerdem, Feyza, "Yerli Dizi Anlatıları ve İzleyici Katılımı: Uçurum Dizisini Ekşisözlük ve Twitter'la Birlikte İzlemek”, Folklor/Edebiyat, 18(72), 2012.

Aksan, Doğan, Türkçenin Sözvarlı̆̆l, Ankara, Engin Yayınevi, 2006.

Aytaçl1, Berrak, "Durum Çalışmasına Ayrıntılı Bir Bakış", Adnan Menderes Üniversitesi Eğitim Fakültesi Eğitim Bilimleri Dergisi, 3(1), 2012.

Bayram, Muhammet Faruk, “Türkiye'de Sahte İhtiyacın Kaynağ 1 Olarak Dizi Filmler”, (Yayımlanmamış Yüksek Lisans Tezi), Hacettepe Üniversitesi Sosyal Bilimler Enstitüsü, Ankara, 2018.

Çal, Ahmet, "Türkiye'de Farklı Dönemlere Ait Kelime Sıklı̆̆g Çalışmaları Üzerine Bir Değerlendirme", Turkish Studies, 10(8), 2015.

Çomak, Nebahat, "Kitle İletişim Araçları ve Dil Sorunları Bağlamında Sözcüklerle Yabancılaşma”, Selçuk İletişim, 2(3), 2014.

Demirtaş, Ahmet, "Sanal Ortamdaki Yazışma Dilinin Türkçeye Etkisi Üzerine", International Human and Civillization Congress from Past to Future Kongresi Kongre Kitabı (387-394), Alanya, 2019.

Durmuş, Oğuzhan, “Alıntı Kelimeler Bakımından Türkçe Sözlük”, A.Ü. Türkiyat Araştırmaları Enstitüsü Dergisi, 26, 2004.

Dursunoğlu, Haluk, "Türkiye Türkçesindeki Arapça Sözcükler ve Bu Sözcüklerdeki Ses Olayları”, Turkish Studies, 9(9), 2014.

Erata, Rüştü, Sachmalama Türkçe de neymiş!, İstanbul, Yap1 Yayın, 2004.

Güllüdağ, Nesrin, "Yazılı ve Görsel Basında Dil Estetiği”, 21. Yüzyılda Ĕğitim ve Toplum, 1/1, 2012.

Günay, Doğan, Dil ve İletişim, İstanbul, Papatya Yayıncılık, 2013.

Güngör, Okan Celal, "Karaçay-Malkar Türkçesindeki Arapça ve Farsça Alıntı Sözlerde Ses ve Anlam Değişmeleri”, Dil Araştırmaları, 25, 2019.

Güzel, Ebru - Karakurt, Arzu, "Dil Yozlaşması ve Söyleyiş Bozukluğu: Televizyon Reklamlarının Göstergebilimsel Açıdan Çözümlenmesi”, Balkan ve Yakın Doğu Sosyal Bilimler Dergisi, 2(4), 2016.

Hacıeminoğlu, Necmettin, Türkçenin Karanlık Günleri, İstanbul, İrfan Yay1nevi, 1976. 
Hepçilingirler, Feyza, Türkçe "Off”, İstanbul, Remzi Kitabevi, 2005.

İşler, Emrullah, Türkçede Anlam Kaymasina Ŭgrayan Arapça Kelime ve Kelime Grupları, İstanbul, Türk Dünyası Araştırmaları Vakfı, 1996.

Karahan, Leyla, "Radyo ve Televizyon Yayınlarında Yöresel Söyleyiş Sorunu, Radyo ve Televizyon Yayınlarında Türk Dilinin Kullanımı" - Tebliğler, Ankara, 1998.

Karahisar, Tüba, "Dijital Nesil, Dijital İletişim ve Dijitalleşen (!) Türkçe" Online Academic Journal of Information Technology, 4(12), 2013.

Kongar, Emre, Yozlaşan Medya ve Yozlaşan Türkçe, İstanbul, Remzi Kitabevi, 2003.

Kurtdaş, M. Çağlar, "Jean Baudrilliard'ın Simülasyon Kuramında Kitle İletişim Araçları ve Toplumsalın Sorunu”, Hitit Üniversitesi Sosyal Bilimler Enstitüsü Dergisi, 11(3), 2018.

Özçakmak, Hüseyin - Yılmaz, Tutku Görkem, "Yediiklim Türkçe Setinde Arapça Kökenli Sözcüklerin Sıklı̆̆ı”, Ana Dili Eğitimi Dergisi, 7(4), 2019.

Silverman, David, Interpreting Qualitative Data: Methods for Analysing Talk, Text and Interaction, London, Sage Publication, 2001.

Subaş1, Münevver - Okumuş, Kübra, "Bir Araştırma Yöntemi Olarak Durum Çalışması”, Atatürk Üniversitesi Sosyal Bilimler Enstitüsü Dergisi, 21(2), 2017.

Şişman, Rabia Şenay, "İş Yeri Adlandırma Eğilimleri: Muş Merkez Modeli”, Turkish Studies, 5(1), 2018.

Türkoğlu, Nurçay, Kitle Illetişimi ve Kültür, İstanbul, Naos Yayınları, 2003.

Yalçın, Melis, "Popüler Kültür Ürünü Olarak Türk TV Dizilerinde Etnografik İletişim Kodlarının Kullanımı: Diriliş Ertuğrul Dizisi Örneği”, İnsan ve Toplum Bilimleri Araştırmaları Dergisi, 5(7), 2016.

Yıldırım, Ali - Şimşek, Hasan, Sosyal Bilimlerde Nitel Araşstırma Yöntemleri, Ankara, Seçkin, 2003.

Yıldız, Osman, "Dilimizdeki Arapça ve Farsça Kökenli Kelimelerde Görülen Fonetik Değişmeler”, SDÜ Fen Edebiyat Fakültesi Sosyal Bilimler Dergisi, 4, 1999.

Yıldız, Ümit - Sertoğlu, Gülsüm, "Esnaf Tabelalarında Yabancı Kelime Dağılımı Üzerine Bir Çalışma”, Route Educational and Social Science Journal, 6(7), 2019. 
Yıldız, Yasemin, "Türkçe Bitki Adlarının Anlam Bilimi Açısından İncelenmesi”, (Yayımlanmamış Doktora Tezi), Sakarya Üniversitesi Sosyal Bilimler Enstitüsü, Sakarya, 2020.

Y1lmaz, Mehmet Fatih, “İnternet Ortamında Şekillenen Söyleşi Dili Üzerine Toplum Dil Bilimsel Bir İnceleme”, Dede Korkut Dergisi, 1(1), 2012.

Yılmaz, Yakup - Özkurt, Emre, "Türkiye'de TV Program Adlarında Türkçeye Uygunluk", Rumelide, 7/1, 2016.

Yin, Robert K, "Case Study Research Design and Methods", 3. bs., London, Sage Publications, 2003.

\section{İnternet erişimleri}

https://www.diziler.com/showtv/dizileri (Erişim Tarihi:03.03.2020).

https://www.diziler.com/kanal/Fox-tv/dizileri (Erişim Tarihi:05.03.2020).

https://www.fox.com.tr/dizi-izle (Erişim Tarihi:03.03.2020).

https://www.kanald.com.tr/diziler/arşiv (Erişim Tarihi:06.03.2020).

https://www.kanal7.com.tr/dizi-izle (Erişim Tarihi:07.03.2020).

https://www.startv.com.tr/site-haritası (Erişim Tarihi:11.03.2020).

https://www.etimolojiturkce.com/kelime (Erişim Tarihi: 13.01.2021).

https://sozluk.gov.tr (Erişim Tarihi:12.03.2020).

https://dizi.yazarokur.com/trt-1-dizileri (Erişim Tarihi:16.03.2020).

https://www.atv.com.tr/diziler/arşiv (Erişim Tarihi:18.03.2020).

https://tiak.com.tr/tablolar\#aylik-tablolar (Erişim Tarihi:01.03.2020). 